\title{
THE UTILITY OF INJUNCTIONS AND DECLARATORY JUDGMENTS IN MIGRATORY DIVORCE
}

\author{
Albert C. Jacobs* .
}

\section{INTRODUCTION}

Of late years a number of decisions have dealt with two attempts to control migratory divorce: first, the injunction against divorce proceedings outside the domicil; ${ }^{1}$ second, the declaratory judgment in regard to the effect of a foreign ex parte divorce. $^{2}$ It thus seems desirable to consider the utility of such relief against socalled migratory divorces. ${ }^{3}$ Let us assume a simple fact situation. A man and a woman marry in State $X$ and there cohabit as husband and wife. After some years a break-up occurs. One party desires to sever the marriage tie. It may be that the laws of State $X$ provide no statutory ground for divorce within which he can effectively fit the case." The other spouse may not be willing to coöperate.

- A.B., I921, University of Michigan; B.A., 1923, B.C.L., 1924, M.A., 1927, Oxford. Associate Rrofessor of Law, Columbia University. Co-author of $A$ Research in Family Law (1930). Published Cases and Materials on Landlord and Tenant (1932); Cases and Other Materials on Domestic Relations (1933).

${ }^{2}$ Di Brigidia v. Di Brigidia, 116 N. J. E.g. 208, 172 Atl. 505 (1934). (1934) 12 N. Y. UNIv. L. Q. Rzv. 135; Knapp v. Knapp, 12 N. J. Misc. 599, 173 Atl. 343 (1934); Perlman v. Pcrlman, I13 N. J. Eq. 3. 165 Atl. 646 (1933); May v. May, 233 App. Div. 519, 253 N. Y. Supp. 606; Dublin v. Dublin, 150 Misc. 694, 270 N. Y. Supp. 22 (1934); Richman v. Richman, 148 Misc. 387,266 N. Y. Supp. 513 (1933), (1934) 34 Cot. L. REv. 172; Johnson v. Johnson, 146 Misc. 93,261 N. Y. Supp. 523 (1933), (1933) 33 Cor. L. REv. 536, (1933) 28 ILL. L. REv. 295.

' Henry v. Henry, 104 N. J. Eq. 21, 144 Atl. I8 (1928); Lowe v. Lowe, 265 N. Y. 197; 192 N. E. 291 (1934), rev'g 241 App. Div. 711, 269 N. Y. Supp. 994 (1934); Schneider v. Schneider, 232 App. Div. 71, 249 N. Y. Supp. 131 (I931); Baumann v. Baumann, 250 N. Y. 382,165 N. E. 819 (1930), (1929) 17 Calif. L. Rev. 681, (1930) 43 Hakv. L. Rev. 477, (1929) 28 Mich. L. Rev. 342, (1929) 14 Mins. L. Rev. 96; (1929) 78 U. of PA. L. Rev. 114; (1928) 38 YALE L. J. I1 I; see also Somberg V. Somberg, 263 N. Y. 1, 188 N. E. 137 (1933), (1934) 47 HARv. L. REv. 1059 (1934); (1934) 82 U. or PA. L. REv. 542.

in regard to migratory divorces, see Cahen, Stattstical Analysis of Amenican Divorce (r932), c. V. Cahen, p. 63, distinguishes migratory or evasive divorces from non-resident divorces, that is, in other than the state of marriage. He comes to the conclusion that not more than three per cent of divorces are migratory. This figure may be low.

"In regard to the statutory grounds for divorce, see 2 Vernier, Amenican Family Laws (1931) 28.72. As to the lack of correlation between the so-called "natural" grounds for divoree and the statutory grounds, sec Mowrer, Family Disorgniziztion (1927).

- This is not the usual set-up, however. Divoree statisties indicate the extent to which coopperation it present in divorce suits. According to the eleventh annual seport of the United States Department o: Commerce, Bureait: of Census, on Marriage and Divorce, issued in 2934 , the contested divorce cases ar1 comparatively. $\mathrm{few}, 13.3$ percent is $1932,13.9$ percent in $1931,12.6$ percent in 1930, 11.8 perecnt is 19292 Ir.7 percent- in 1928 , and 15.4 . percent between 1887 and 1906. 
The first spouse decides to take advantage of the laxer divorce laws of some other state or country, where perchance there are more statutory grounds for divorce, where the courts may be more lenient in their divorce administration, and where the residence requirements are inviting.

With the effect of absolute divorces obtained in other states and countries we are not primarily concerned. Our law reviews are filled with discussions of the effectiveness of such decrees. ${ }^{7}$ The American Law Institute in the Restatement of Conflict of Laws ${ }^{8}$ has endeavored to deal with these problems. The National Conference of Commissioners on Uniform State Laws in 1930 approved a Uniform Divorce Jurisdiction Act. ${ }^{\circ}$ But still the ghosts of the Supreme Court cases of Atherton v. Atherton, ${ }^{10}$ and Haddock v. Haddock, ${ }^{11}$ linger to haunt us. Clarity is lacking. The complexing problems have not been effectively settled. Parties may be regarded as divorced in one state and yet as married in another. The disparity between the policies of the various states in regard to the nature of the divorce action, $^{12}$ in regard to the various statutory grounds for divorce, ${ }^{13}$ in regard to the requirements of residence, ${ }^{14}$ and in regard to the recognition of ex parte decrees, has all added to the confusion. Of late years, the legislatures of some states have seen fit to relax materially the residential requirements. ${ }^{15}$ New divorce "markets" have entered the field. ${ }^{10}$

Our interest centers primarily on the spouse who is unwilling to coöperate in the foreign divorce. Of course, he or she can stand by while the other proceeds to obtain a final foreign decree without contest, and then, if still desirous of enforcing his or her marital rights, can do so in various ways. ${ }^{17}$ To what extent,

-In regard to the residence requirements in the various states, see 2 VERnrer, op. cit. supta note 4, 106-113.

'A sampling of the authorities in this fiell is as follows: Beale, Constitutional Protection of Decrees for Ditorce, (rg06) ig Harv. L. Rev. 586; Bcale, Haddock Revisited (I926) 39 HARv. L. REv. 417; Greenc, Enforcement of Forcign Divorce Decree in New York (1926) II CoRN. L. Q. 141; Hzrper, The Validaty of Void Divorces (1930) 79 U. OF PA. L. REy. 158; McClintock, Fault as an Element of Divorce lurisdiction (I928) 37 YALE L. J. 564 .

Restatement, Confuct of Laws (1934) $95110-214$, inclusive.

' 9 U. I. A. 133. So far Vermont is the only state to adopt this act. Vt. Jaws 1931, No. 45. Huw. ever, in 1933 Vermont repealed it, Vt. Laws 1933 , No. 38, thus leaving no 2dopting states.

18r U. S. 155 (rgor).

11201 U. S. 562 (1906).

23 That is, whether a divorce suit is in the nature of an action in rem or an action in personam.

28 See note 40 supra.

IB Nev. Sess. Laws 1931, c. 97, 522, p. 161 (six weeks); IDAHo Code 4NN. (1932) 5531-701 (ninety days); Ark. Acts 1931, No. 71, p. 201, (ninety days). See 2lso Squire v. Squire, 186 Ark. 511,54 S. W. (2d) 281 (1932).

10 The popularity' of Paris as a divores "mecca" seems to have declined since 1927 , due to an increase in the cost thercof and in the residence requirement. See Bates; The Divorce of Americans in France, supra, p. 322. Mexico seems to have replaced Paris as a foreign divorce haven. Arkansas and other states have entered into competition with Nevada. See note 15 , supra.

For a good picture of the divorce practice in Nevada, Arkansas, etc., see Note (1932) 17 Mins. 1. REv. 638. And ste Ingram and Ballard, The Business of Migratory Divorce in Nevada, supra, p. 302. The divoree rate per 1,000 population in 1932 was 1.28 for the whole United States, but 42.89 for Nevada.

${ }^{27}$ For example, where the ex parte divorce has been secured by the husband, the wife, if she so desires, can immediately bring an action for the maintenance of herself and their children. See Note 
however, can the non-agreeing spouse petition in equity for an injunction to restrain the other from secking a divorce outside the domicil? Under what circumstances will such an injunction issue? And if such an injunction be granted, how effective will it be? Or again, suppose that the one spouse has proceeded to another state or country and there procured an absolute ex parte divorce, and later such spouse returns to State $X$. Can the other obtain a declaratory judgment to the effect that this decree of divorce is void? These problems will be dealt with in order.

To clarify the issues, it is necessary to note certain natural limitations which are placed upon the scope of this article. In the first place, we are concerned only with the set-up where one spouse secks to obtain or obtains a migratory divorce against the wishes of the other. This materially limits the actual number of cases with which we must deal. ${ }^{18}$ In the second place, this article does not purport to deal extensively with the Constitutional or conflict of laws principles governing the recognition and effectiveness of ex parte decrees of divorce. In our limited set-up no question of the full faith and credit clause of the Constitution in regard to migratory divorce is directly involved. ${ }^{19}$ Furthermore, it must be remembered that

(1930) 43 Harv. L. Rev. 477, 478, n. 7. Also the cases cited in note 102, infra. Shie may sue independently for divorce and for alimony. It seems quite well settled that where the husband has brought the forcign action for divorce and the wife has not appeared, that the latter can obtain alimony at home, though the theories on which this is done vary. See Thurston v. Thurston, 58 Minn. 279,59 N. W. 1017 (1894); Toncray v. Toneray, 123 Tenn. 476, 131 S. W. 977, (1910); cf. Joyner v. Joyner, 131 G2. 217, 62 S. E. 182 (igoz); see Jacobs, Cases and Materiats on Domestic Relations (1933) 990, n. 4. Aftes the death of the spouse who has procured the forcign ex parte divorce, as to whether the other party may claim rights of dower or of curtesy or the statutory substitute therefor in the property of the deceased, see Whecler, The Effect of Foreign Divorce upon Dower and Cursesy (1927) 25 Mrck. L. Rev. 487 (1927); also N. Y. Decedent Estate Law, N. Y. Cons. Lnws (Cahill, 1930) c. 13, 587, quoted infra, note 103.

1* We have seen, note 3 , supra, that not more than three percent of American divorees are of a migratory character. On this basis, in 1932, there would have been about 4,810 migratory divorces. This figure is probably low. In 1932 there were 3,989 divorees in Nevada alone, or 56.3 per 100 marriages. We have seen further, note 5 , supra, that approximately 85 percent of our divorces are not contested, from which we can safely infer, I believe, that in the great majority of cases the divorce was obtained with the consent of the respondent. In 1932, however, 2,277 of the 3,989 Nevada divorees were at least formally contested.

${ }^{2}$ U. S. Consr. Art. IV, 51 : "Full faith and credit shall be given in each state to the public acts, records, and judicial proceedings of every other state. . .."

It seems to te clearly settled that a decree of absolute divorce is entitled to full faith and credit in the following situations: (1) Where rendered at the domicil of both parties, even though service is by publication only. Restatement, Conflict of Laws (1934) 5r10. (2) Where rendered by 2 court of the last matrimonial domicil of the spouses, even though one spouse may be domiciled elsewhere at the time of the decree and service be by publication only. Atherton v. Atherton, supra note 30; see also Haddock v. Haddock, supra note II; also Restatement, supra, fr13b, and comment f. (3) Where rendered by $a$ court of the domicil of the complainant spouse only if the defendant is personally served within the state or appears. See Haddock v. Haddock, supra note II; REsTatemENT, supra, SII32 (iii), and comment $d$.

The Restatement goes still further and provides, $\$ 113$ : " $\Lambda$ state can exercise through its courts jurisdiction to dissolve the marriage of spouses of whom one is domiciled within the state and the other is domiciled outside the state, if (a) the spouse who is not domiciled in the state ( $x$ ) has consented that the other spouse acquire 2 separate home; or (2) by his or her misconduct has ceased to have the right to object to the acquisition of such separate home. ... This follows Professor Beale's interpretation of the Supreme Court decisions of Atherton v. Atherton, supra, and Haddock v. Haddock, supra, making "fault" the determining factor where the divorce is granted in the domicil of one spouse bascd upon constructive service on the other. For a criticism thercof, see McClintock, Fault as an Element of Divorce 
the majority of states will, on the ground of comity, recognize ex parte decrees of divorce obtained in a state of the domicil of the complaining spouse even though service on the other was by publication only. ${ }^{20}$ As far then as the policy of this large group of states is concerned, where a bona fide domicil ${ }^{21}$ has been established by one spouse in the state of the divorce, this paper is not concerned. Our interest then is centered around the cases where one spouse seeks to obtain or has obtained a divorce in another jurisdiction without a bona fide domicil and against the wishes of the other.

\section{The Injunction Restraining Drvorce Proceedings. Outside the Domacil ${ }^{22}$}

In developing this aspect of our problem, it is my purpose to consider, first, the general nature of this type of remedy, second, the factors conditioning its issuance, and third, its effectiveness, that is, both in regard to the equity defendant and in regard to the foreign divorce court. These points will be considered in this order. ${ }^{28}$

\section{A. General Nature of Injunction Restraining Foreign Proceedings}

For a long time it has been settled that courts of equity will, under proper conditions, enjoin the bringing of an action in a foreign tribunal. ${ }^{24}$ The early refusal of the English Courts of Chancery to grant this type of relief was due to a misJurisdiction (1928) 37 Yase I J. 564. For a recent case adopting the position of the Restatement, see Delanoy v. Delanoy, 216 Cal. 27, I3 P. (2d) 719 (1932), (1933) 21 Catur. L. Rev. 504; Note (I933) 86 A. L. R. 1329.

In our typieal set-up, however, none of these problems is involved. Nor does any question of estoppel appear, the absent spouse in no way having submitted to the jurisdiction of the court or having acted in reliance upon the ex parte decree. See Restatenent, supra, 55112, 45T.

${ }^{50}$ Gildersleeve v. Gildersleeve, 88 Conn. 689, 92 Aul. 684, 920 (1914); see also Ditson v. Ditson, 4 R. I. 87 (1856). Contra: People v. Baker, 76 N. Y. 78 (1879); Perkins v. Perkins, 225 Mass. 82, 113 N. E. 84 (Ig16); see also Haddock จ. Haddock, supre note 11.

$n$ Domicil is 2 jurisdictional fact and is subject to attack. Restatement, Confuct of Laws 5 IxI, comment a: "A finding of domicil by a court in a divorce proceediag cannot create jurisdiction. Domicil, like any other jurisdictional fact, is subject to collateral attack in any other state by a party who was not personally before the court when the decree of divorce was granted. . .. " Thus, where 2 divorce comes before a court of another state, despite a finding of domicil of the plaintiff by the divorce court, it may be shown by extrinsic proof that the plaintiff was not in fact a bona fide domiciliary of the state which granted the decree. State v. Cooke, IIo Conn. 348, 148 Atl. 38\& (1930).

Much bas been written on the subject of the injunction against foreign proceedings. For 2 sampling of the authonities, see Mesner, The Jurisdiction of a Court of Equity Over Persons to Compel the Doing of Acts Outside the Territorial Limits of the State (1930) 14 M.NN. L. REv. 494, 495-506; Pound, The Progress of the Low-Equity (1920) 33 Huxv. L. Rev. 420, 425-428; Foster, The Place of Trial in Ciest Actions (1930) 43 Harv. L. Rev. 1217, 1240-1248; 2 Story, EQuity Jurispridence (14th ed., 1918) 551224-7>25: the following notes snd mmments: (1922) 22 CoL. L. REV. 360; (1919) 33 HARv. L. REv. 92; (1922) 35 Haxv. L. Rev. 610; (1932) 31 Mrch. L. Rev. 88; (1933) 31 Mich. L. Rev. 963; (1924) 72 U. of PA. L. Rev. 429; (1930) 39 Yale L. J. 7r9; (1921) ro Geo. L. J. 47.

* Wherever possible the discussion will be limited to the fact-situation before us. In many instances, however, it will be necessary to argue by analogy from injunctions against other types of proceedinge: This latter type has become common. There are not many reported cases, however, dealing with the injunction restraining divorce proceedings, and with one exception, all have issued from New Jersey and New York. See notes 50, 5x, infra.

2 STokY, loc. cit. supre note 22. 
apprehension of the nature thereof. ${ }^{25}$ With a better understanding of such injunctions the jurisdiction of the equity courts to grant them became firmly established both in England ${ }^{28}$ and in America. ${ }^{27}$ It has frequently been pointed out that the injunction does not interfere with the sovereignty of the other state or country; that it is a decree in personam directed to the parties to the suit. ${ }^{28}$ With this view the overwhelming weight of American authority is in accord. It has definitely been settled that the granting of such an injunction does not violate the full faith and credit clause, ${ }^{28}$ or the interstate privileges and immunities clause $e^{80}$ of the Federal Constitution. ${ }^{31}$ Furthermore, the courts have deemed it no violation of the principles of comity to interfere with the bringing of certain suits in other jurisdictions." "The theory upon which the courts act, in granting this relief, is that they have authority to control the persons within the territorial limits of the State, and, having jurisdiction of the parties, can render a decree which the parties are bound to respect and obey, even beyond the territorial limits of the State."3s

\section{B. Factors Conditioning the Use of this Type of Injunction}

To understand the basis of the injunction against outside action, it is necessary to consider the appropriate forum in which to bring a civil suit. In other words, what is the normal place to try a case: is it [i] the residence of the plaintiff; [ii] the

${ }^{2}$ In one of the earliest reported cases, Love v. Baker, 2 Freeman Ch. 125, I Ch. Cas. 67 (1665), it was held that an injunction did not lie to stop 2 suit at Leghorn.

20 Wharton v. May, 5 Ves. Jr. 27 (1799); Bushby v. Munday, 5 Madd. 297 (182r). In Portarlington v. Soulby, 3 My. \& K. 104 (1834), the chancellor, Lord Brougham, stated, at p. 108: "In truth, nothing can be more unfounded than the doubes of the jurisdiction. That is grounded, like all other jurisdiction of the Court, not upon any pretension to the exercise of judicial and administrative rights abroad, bus on the circumstance of the person of the party on whom this order is made being within the power of the Court." [Italics author's.]

"Sce Cole v. Cunningham, 133 U. S. 107 (1890).

2 Bigelow, C. J., in Dehon v. Foster, 4 Allen (86 Mass.) 545 (1862); "In the exercise of this power, courts of equity proceed, not upon any claim of right to interfere with or control the course of proceeding in other tribunals, or prevent them from adjudicating on the rights of the parties when drawn in controversy and duly presented for their determination. But the jurisdiction is found on the clear authority vested in courts of equity over persons within the limits. of their jurisdiction and amenable to process, to restrain them from doing acts which will work wrong and injury to others, and are thercfore contrary to equity and good conscience."

$\rightarrow$ Art. IV, \$1, quoted, supra note 19.

${ }^{20}$ Art. IV, $3_{2}(\mathrm{I})$. "The citizens of each state shall be entitled to all privileges and immunities of citizens in the several states."

" Cole v. Cunningham, supra note 27, where it was held not to be a denial of full faith and credit to New York judicial proceedings for a Massachusetts court, on the application of a resident thereof, to enjoin another Massachusetts resident from prosecuting in New. York 2 garnishment action already commenced there, in evasion of the laws of their domicil. For a challenge of the soundness of the doctrine of this case, see Langmaid, The Full Faith and Credis Required for Public Acts (1929) 24 IL2. L. REv. $383,408$.

2 Comity between the states and public policy were the reasons early advanced for the refusal of a few American courts to interferc, even in this indirect manner, with proceedings in the courts of sister states. See Boyd v. Hawkins, 17 N. C. 329 (1833); Mead v. Merritt, 2 Paige 402 (N. Y. $\times 831$ ).

¿x Mesner, supra note.22, at 495; see also Keyser v. Rice, 47 Md. 203 (1877); 2 StokY, loc. cit. supra note 22. 
residence of the defendant, or [iii] the place where ihe transaction happened? ${ }^{34}$ In regard to civil cases in general, we start with the recognition of the common law attitude that a plaintiff ordinarily may sue in whatever state has jurisdiction of the defendant. We are confronted, however, with another equally broad and general principle, namely, that equity will prevent the unconscionable enforcement of a legal right. Were our problem to consider the injunction against an ordinary suit in a foreign state, that is, a suit which normally could be maintained there by a nonresident, it would be necessary to consider at what point will be reconciled the competing considerations of policy behind these two general principles. For instance, would equity enjoin the institution of a suit at a place other than the normal place, as a matter of course? We are dealing, however, in our particular fact set-up, with the injunction against divorce proceedings. Jurisdiction to grant divorce depends upon domicil, ${ }^{38}$ at least domicil of one of the spouses. ${ }^{30}$ Many other types of litigation often enjoined can be maintained by non-residents-not so with divorce, where domicil of one spouse is necessary to sustain jurisdiction. Technically, therefore, the problem of the proper forum looms less large here than it does in the ordinary civil case. ${ }^{37}$ Theoretically at least, the choice of the proper forum is narrowed materially. Until there is a change of domicil of one or both spouses, there can be only one appropriate tribunal, the only state interested in the proceedings. ${ }^{38}$ Particularly will the matrimonial domicil consider itself the proper court. Where the spouses become domiciled in different states, there will perchance be competing claims as to the appropriate divorce forum. ${ }^{39}$

When then will an injunction against foreign proceedings be granted? Pound ${ }^{40}$ has given us perhaps the most lucid classification of the situations. First, when the foreign court has no jurisdiction, but the threatened judgment there would embarrass the equity plaintiff in the assertion of his or her rights. ${ }^{11}$ Second, where concurrent litigation between the same parties over the same subject matter is in prog-

"For a more detailed discussion of these problems, see Foster, The Place of Trial in Civil Actions (1930) 43 Harv. L. Rev. 1217; Foster, Place of Trial-Interstate Application of lntrastate Methods of Adjustment (1930) 44 Haxv. L. REv. 41; Blait, The Doctrine of Forum Non Conveniens in AngloAmerican Law (1929) 29 Col. I. Rev. 1; Dainow, The Inappropriate Forum (1935) 29 ILL. L. REv. 867.

"Restatement, Conflict of LAws, 51II: "A state cannot exercise through its courts jurisdiction to dissolve a marriage when neither spouse is domiciled within the state."

Compare f112: "The validity of a divorce decree cannot be questioned in 2 proceeding concerning any right or other interest arising out of the marital relation, either by a spouse who has obuined such decree of divorce from a court which had no jurisdiction, or by 2 spouse who takes advantage of such a decree by remarrying."

${ }^{20}$ See note 19, supre. Compare, however, Gould v. Gould, 235 N. Y. 14, 138 N. E. 490 (1923), where 2 French divorce, based on adultery, between Americans domiciled in New York but long resident in France was recognized in New York on the ground of comity.

" Of course, one spouse can always establish a bone fide domicil in another state and after satisfying the residence requirements there prescribed by statute, proceed to 2 divorce. As to the recognition of such 2 decree elsewhere, see note 19, supra.

25e note 21, supra, to the effect that domicil is a jurisdictional fact.

- See Ditson v. Ditson supra note 20.

"Pound, The Progress of she Law-Equity (1920) 33 Hanv. L. Rxv. 420, 425-428.

4 Id. $2 t$ 426. In this group is put the injunction restraining foreign divorce proceeding* 
ress or is threatened. ${ }^{42}$ Third, where there is an attempt to reach exempt property of a domestic debtor by means of an action outside the state. ${ }^{43}$ Beyond this it is difficult to go. Just what constitutes a proper case for the exercise of such power has never been adequately answered. ${ }^{41}$

Returning now to the injunction restraining foreign divorce proceedings, in Johnson v. Johnson, ${ }^{45}$ Heffernan, J., said: ${ }^{46}$

"The question, however, as to when this jurisdietion may be exercised is often one of great delicacy, owing to the fact that it may frequently lead to a conflict of jurisdiction. Hence the power is used sparingly, and the applicant must show good equitable grounds"t

Ibid.: "In some of the cases of this type there was simply 2 vexatious multiplicity of actions. [Frencb v. Hay, 22 Wall. (U. S.) 250 (1874)]. Here courts were cautious about interposing. [Burgess v. Smith, 2 Barb. Ch. (N. Y. $276,280(1847)$ ] In others, one court was not in 25 good a position to do complete justice as another. [See Harris v. Pullman, 84 Ill. $20(1876)$ ]. In still others, the defendant was sceking to obtain an inequitable advantage over other creditors by means of concurrent litigation abroad. [Cole v. Cunningham, note 27, supra]."

Snook v. Snetzer, 25 Ohio St 516 (1874).

Pound, supra note 40, at 427: "To these [the above three types of cases] some courts are adding a fourth: Cases where the foreign court has jurisdiction, in which there is no concurrent litigation or vexatious multiplicity of action, and in which there is no attempt to reach anything which the policy of the local legislation seeks to secure to the plaintif, but in which 2 domestic creditor secks to sue a domestic debtor, as he has full legal power io do, in another state, where the latter has property, because of a more favorable procedure or more favorable views as to what is a defense in the latter jurisdiction."

To these should we possibly add a fift-"Forum non conveniens"?

4 Restatement, Conflict of LAws \$96: "A state can exercise-through its sourts jurisdiction to forbid 2 party, who is subject to its jurisdiction, to do an act in another state."

Comment a: " . . . Whether a decree of this character will be rendered depends upon the principles of equity jurisprudence as understood and developed by the courts of the forum and is no part of the Restatement of this subject. It may be stated, however, that when acts are threatened which subject the plaintiff to irreparable damage os when the balance of convenience and fairness require, such a decree will readily be issued."

Supra note 1 . In an action for separation on the ground of abandonment and for separate maintenance the "wife sought permanently to enjoin her husband from instituting legal proceedings for divorce in Nevada or in any other jurisdiction. The spouses had resided in New York for ten years. The defendant was served in New York and failed to deny that he bad none of the legal grounds for divorce and that he intended to set up a fictitious residence elsewhere to secure a divorce on grounds not recognized in New York. Held, a temporary injunction granted, testraining him from prosecuting a divorce action in any other jurisdiction.

"Supre note 1, at 95.

"See Dehon v. Foster, 86 Mass. 545, 551 (1862). .

Cf. Note (1933) 31 Mich. L. REv. 88: "It is frequently said that it will be exercised but sparingly, and then only when a clear equitable right is established by the petitioner. This, in spite of the strong language commonly accompanying such statements, is no more than that which the court requires for the issuance of any injunctional decree. The same equitable principles upon which is based the issyance of an injunction elsewhere are equally controlling here."

Id. at 92: "It may be suggested that what have been termed delicate considerations involved in interfering with legal proceedings in other states,' are of no aid in arriving at a decision, and should be discarded as merely producing additional confusion in an already diffcult problem. ... The true basis .. should involve only an application of the usual equitable principles."

Pound, supre note 40 , at 426: "Undoubtedly 2 state may cocree its citizens not to sue abroad. It does not follow, however, that its courts of equity have jurisdiction to do so in every case, or that they ought to exercise such jurisdiction in every case where it exists. We have to ask: What are the legal rights of the plaintiff in equity, defeadant abroad, and are the legal remedies which are open to him adequate to mairtain those rights? We have then to ask: is the injustice and hardship upon the plaintiff such as to make it expedient for equity to act, in view of the delieate considerations involved in interfering with legal proceedings in other states?" 
or the injunction will not issue. The jurisdiction rests on the authority vested in courts of equity over persons within the limits of their own jurisdiction to restrain them from doing inequitable acts to the wrong and injury of others, and on the power of the State to compel its own citizens to respect its laws even beyond its own territorial limits. All that is necessary to sustain the jurisdiction is that the plaintiff should show a clear equity and that the defendant is subject to the authority and within reach of the process of the court, and this requirement is satisfied when it is shown that the institution of the suit in another state is for the purpose of securing to the plaintiff some unfair, unconscionable or inequitable advantage, or that the prosecution thereof will result in fraud, gross wrong or oppression, and that the prosecution of the suit in another state is against equity and good conscience, or that the suit is against the public policy of the state in whose court the injunction is sought. ${ }^{8}$ The most frequent ground for granting an injunction of this character is to prevent a citizen of one state from prosecuting an action against another citizen of the same state for the purpose of avoiding the laws of his own state."48

The courts of New Jersey, ${ }^{50}$ New York, ${ }^{51}$ and Rhode Island ${ }^{52}$ have issued injunctions restraining foreign divorce proceedings. The statutory grounds for divorce in New Jersey and New York are set forth in the footnotes. ${ }^{63}$

An analysis of the reported cases where an injunction has been granted restraining foreign divorce proceedings shows that the issuance thereof has been based on one or more of three principal grounds. First, the foreign divorce would involve an evasion of the laws of the domicil or of a strong domestic policy. In.this, as in other fields, ordinarily where the purpose of the foreign suit is to evade the laws of

\footnotetext{
“Greenberg v. Greenberg, 218 App. Div. 104, 218 N. Y. Supp. 87 (1926), (1927) II Mrsw. L. Rrv. 467, Dowling, J., at p. I12: "This jurisdiction of the courts of our state has been exercised repeatedly in matrimonial cases. This State has settled as its adjudged policy to refuse to recognize as binding a decree of divorce obtained in'a court of 2 sister State, not the matrimonial domicil, upon grounds insufficient for that purpose in this State, when the divorced defendant resided in this State and was not personally served with process and did not appear in the action. . . .

"To protect the citizens of this State in their rights, it is not necessary that the offending litigant should be allowed to carry through his scheme of evasion of the laws of his own State to a successful completion, and leave the aggrieved party to defend his rights against such a judgment, so fraudulenty obvained, when it is set up in some proceeding here."
}

For recent applications of this policy, see Fischer v. Fischer, 254 N. Y. 463, I73 N. E. 680 (1930),

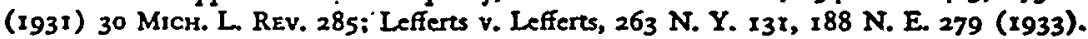

For New York policy where the divorce defendant is not 2 New York resident, see Ball v. Cross, 231 N. Y. 329,132 N. E. 106 (192I); (1921) 31 YALE L. J. I91; Dean v. Dean, 24I N. Y. 240,149 N. E 844 (1925); (Ig26) 39 HAxv. L. REv. 640.

- See Greenberg v. Gecenberg, supra note 48, at 115 .

- Kempson v. Kempson, 58 N. J. Eq. 94,43 Atl. 97 (1899); Streitwolf v. Streitwolf, 58 N. J. Eq. 563,41 Atl. 876, 43 Atl. 683, 630 (1899), aff'd 18x U. S. I79 (1901); Huettinger y. Huettinger, 43 Atd. 574 (N. J. 1899); Miller v. Miller, 66 N. J. Eq. 436; 58 At. 188 (1904); Von Bernuth v. Von Bernuth, 76 N. J. Eq. 177, 73 Atl. 2049 (1909); Perlman v. Perlman, supra note 1; Knapp v. Knapp, supre note 1; Di Brigidia v. Di Brigidia, supra note 1 .

"Forrest v. Forrest, 2 Edm. Sel. C2s. 180 (N. Y. 1850); Kittle v. Kittle, 8 Daly 72 (N. Y. 1878); Gwathmey v. Gwathmey, I16 Mise. 85, I90 N. Y. Supp. I99 (I921); affd 201 App. Div. 843, 193 N. Y. Supp. 935 (1922); Greenberg จ. Greenberg, supra note 48; Johnson v. Johnson, suppe note 1; Dublin v. Dublin, supre note I; Richman v. Richman, supre note 1.

Injunction denied: May $\mathbf{r}$. May, supra note 1.

Borda v. Borda, 44 R. 1. 337, I17 At. 362 (1922).

- New Jersey: Adultery, Conce. Stat. (I9ro) p. 2023, S2; Cruelty, Cunc. Surp. (r924) p. 9b9s 562-32; Desertion, for two years, Cover. Stat. (29ro) p. 2023, S2; p. 2041, 331.

New York: Adultery, Civ. Puc. ACT (C2hill, I925) Srra7. 
the domicil, an injunction will be granted. ${ }^{54}$ Especially is this true of suits for divorce. The state of the domicil takes a peculiar interest in the preservation of the marital status. It does not allow the parties by private contract to alter the normal incidents thereof or to arrange for a divorce. ${ }^{\text {b5 }}$ Many of the New Xork cases proceed on this ground. ${ }^{86}$ With a strict divorce law such as New York and with a policy against the recognition of ex parte decrees, ${ }^{57}$ it is not surprising to find there a relatively large number of injunctions against foreign divorce.

Second, many cases proceed on the basis of undue hardship. of the threatened forcign divorce proceeding on the equity defendant. 58 The situation facing the equity plaintiff has been well described by Pitney, V. C., in Kempson v. Kempson:s0

"She is in this predicament-she must either ( $\mathrm{r}$ ) go to the trouble and expense of appearing generally in the Dakota court to resist her husband's claim, ${ }^{00}$ or (2) she must attempt to appear specially for the purpose of contesting the jurisdiction of the court by showing his real domicil to be in New Jersey. Either of these defences involves great labor and expense on her part. 81 The only other course open to her is, in substance, to allow judgment by default to go against her there, and attack the decree when attempted to be enforced in this State. Now, if she adopts the first remedy and appears in that court, it will, by that appearance, have obtained jurisdiction of her person and undoubted jurisdiction of the subject-matter of the suit, as the case then will be brought within the

\& Miller v. Gittings, 85 Md. 601, 37 Atl. 372 (1897).

Foster, supra note 22, at 1241 : "The principal reason for issuing injunctions is fear that the forcign court will not decide the issue properly, and conviction that the home state has a strong interest in having the. issue determined according to its own views."

In regard to collusion, see $i$ VernJER, op. cir. supra note $4,75-77$.

* (1932) 3r. Mich. I. Rev. 88, 93: "It is generally said that where a suit in a forcign jurisdiction would result in an evasion of a strong domestic policy, such will be enjoined. . . Hence, a decree has generally issued either where one spouse seeks a divorce abroad and proceeds without complying with the laws of the foreign state, or where the decree otherwise would not be effective in the domiciliary state."

See Gwathmey v. Gwathmey, supra note 51.

- See Greenberg. v. Greenberg, supre note 48; Forrest v. Forrest, supre note 5I; Kittle v. Kittle, supra note $5 x$.

Kempson v. Kempson, supra note 50; von Bernuth v. von Bernuth, supra note 50; Perlman v. Perlman, supre note I; Forrest v. Forrest, supra note 5r; Kittle v. Kittle, supra note 51; Greenberg v. Greenberg, supra note 48; Gwathmey v. Gwathmey, supra note 51; Johnson. v. Johnson, supra note x; Richman v. Richman, supro note 1.

${ }_{5} 8$ N. J. Eq. 94, 95, 43 Atl. 97 (1899).

- Kittle v. Kittle, supra note. 5I, Daly, C. J., said in regard to a separation suit brought by the husband in Connecticut during the pendency of a similar suit brought by the wife in New York on the same grounds: "The plaintiff swears that it is the intention of the defendant to bring the action in Connecticut to trial before it will be possible for the cause to be tried over again in this court, and that it will not be in her power to give evidence in defence of that action, as all her witnesses reside in this state, except two, who reside at Hoboken in New Jersey, and that being wholly without means, she can neither pay the expense that would be incurred by having their testimony taken by a commission in this state, nor pay their-expenses in going from this state to Connecticut, as witnesses, to testify in her behalf. . .

"The plaintiff is helpless as respects the suit in Connecticut. It is not in her power to defend it, and Judgment may be there-rendered against her through her inability to make any defenee from want of testimony. Full and ample justice can be done to the defendant in this suit."

or Johnson v. Johnson, supre note x, p. 95: "Undoubtedly plaintiff by employing counsel and appearing in forcign court could defeat defendant's attempt to obtain a decree against her. To resist such an attack upon her marriage she would be required to appear and make her defense in some remote foreign forum chosen by defendant. This course would also necessitate the expendinure of considerable moncy. and plaintiff pleads that she is penniless, in delieate health and incumbered by two small children." 
authority of the case of Fairchild $v$. Fairchild, 8 Dick. Ch. Rep. 678,82 as the decree of that court will be binding upon her. ${ }^{68}$ As to the second course, namely, a special appearance for the purpose of attacking the jurisdiction, it is common knowledge that the courts of Dakota assume jurisdiction of non-resident defendants based on a residence on the part of the plaintiff which falls far short of amounting to an actual domicil. In fact, they are satisfied with a mere temporary residence adopted for the purpose of obtaining 2 divorce, and without any animus manendi; so that, if she should appear specially, the task of satisfying the court that her husband was not a bona fide domiciled resident of the State would be well-nigh hopeless. ${ }^{64}$ If she takes the remaining course, and fails entirely to appear, and allows a decree to go against her, she will be in the situation of a divorced wife, who must bring a suit to set aside the decree of divorce and enforce her rights against her husband, who may avoid personal service in this jurisdiction. This is a hardship to which it seems to me the husband has no right in equity to subject her." 15

Third, many cases base the injunction against foreign divorce upon the ground of fraud. ${ }^{\circ 6}$ That is, the equity plaintiff alleges that the equity defendant has no. intention of establishing a bona fide domicil in the divorce state; that therefore a fraud is about to be perpetrated upon the court of that State, and upon the equity petitioner. Particularly is this true of the New Jersey cases. ${ }^{\circ 7}$

- Fairchild v. Fairchild, 53 N. J. Eq. 678, 34 Atl. to (1896). Husband's divorce obtained in Kansas, wife appearing, held a defense to wife's suit for separate maintenance; that the bone fides of the husband's residence could not be questioned in New Jersey, in the absence of fraud.

- Suppose the wife appears to contest her husband's suit and loses, could she later attack such decree in the state of her domicil? In Schneider v. Schneider, 232 App. Div. 71, 249 N. Y. Supp. 131 (1931), she was not allowed a declaratory judgment that her husband's French divorce was void. See note 163 , infra.

Restatement, Confuicr of LAws, 5451: "A party appearing and participating in a court of any state will be precluded from questioning the jurisdiction of the court over his person in any subsequent procecding in that state, or in any other state if the court in which he appeared purported to render 2 .judgment against him."

Caveat: "The Institute expresses no opinion whether and how fas a party appearing and participating in the proceedings in a court of any state is precluded from subsequently questioning the jurisdiction of the court over the subject matter of the action in the courts of that state or any other state if the court in which he appeared purported to render 2 judgment against him."

Illustration: "A sues $\mathrm{B}$ in Nevada for divorce. B enters an appearance and pleads that neither $A$ nor" $B$ is domiciled in Nevada. The court finds that $\Lambda$ is domiciled in Nevada and renders a decree of divorce 2gainst B. Subsequently $B$ sues $A$ in Illinois for 2 divorce. A pleads the Nevada decree. The careat leaves open the effect of the Nevada decree."

See, however, Andrews จ. Andrews, 188 U. S. I4 (1902). White, J., "Nor is there force in the suggestion that because, in the case before us, the wife appeared, hence the South Dakota court bad jurisdiction to decree the divorce."

4 See note 125, infra.

- Sec Greenberg v. Greenberg, supra note 48, at 112.

- Streitwolf v. Streitwolf, supra note 5o; Huettinger v. Huettinger, sripra note 50; Kempson v. Kempson, supra note 5o; Perlman v. Perlman, supra note I; Knapp v. Knapp, supra note I; Di Brigidia $\nabla$. Di Brigidia, supra note I; Forrest v. Forrest, stupra note 51; Dublin v. Dublin, supra note $x$.

" Di Brigidia v. Di Brigidia, supra note I. The husband had secured a Nevada decree for eruelty occurring in New Jersey. The wife, served with process in New Jersey, did not appear. The divoree was set up as a defense to the wife's suit for support and maintenance. . Wife's replication alleged fraud in procuring the decree, because there had been no bona fide domicil in Nevada. During the pendency of the husband's divoree action, the wife had instituted a suit for support, the husband being personally sarved in Nevada with the complaint and an order restraining him from proceeding with the divorce. No notice of this was given to the Nevada court. Held, the divorce was void, as it was secured by fraud going to the jurisdiction. "And yet, knowing that during the whole period be sojourned in Nevada, be 
It is generally stated that for an injunction to issue, both parties must be resident of the enjoining State. ${ }^{68}$ Hence, even in regard to an ordinary transitory cause 0 action, if either the equity plaintiff ${ }^{69}$ or defendant ${ }^{70}$ is a non-resident, as a genera rule, no injunction will issue. Due to the peculiarities of divorce jurisdiction, ${ }^{71}$ thi applies with far greater force to the injunction against foreign divorce proceedings If the equity petitioner is not a resident of the state, no injunction should issue ti restrain the divorce proceedings. ${ }^{72}$ It is only on the basis of residence and citizen ship that he is entitled to the protection of its marital laws. ${ }^{78}$ Similarly, in thi absence of residence and domicil of the equity defendant, an injunction would seen to be useless. ${ }^{\text {Tt }}$ In all but one case ${ }^{78}$ where the injunction restraining divorce ha:

was, nevertheless a sesident of New Jersey, he intentionally conecaled from the Nevada court the fact tha this court had restrained him from proceeding. This being so, it is manifest that be procured the ad. judication of the Nevada court on the question of his domicile by fraud."

See also Miller v. Miller, supra note 50; Knapp v. Knapp, sugra note 1; Huettinger v. Huettinger, sispre note. 50 .

- Note (1932) 31 Mich. L. REv. 88, 95, discusses the general situation: "It might be said ... unlest both parties are residents of the state in which the injunction is sought, relief will usually be refused. This would not seem to lead to an untoward or unjust result. Where there is real hardship in being sued abroad, or if the action is being brought for the purpose of vexation, an appeal may always be made to the foreign court. In the case where 'evasion of domestic policy' is alleged, if the plaintiff be not a citizen he has ro right to the protection afforded by the policy, and if the defendant is a stranger he is not bound by it."

- The great majority of American decisions have held that an injunction against suit in anothes state will not be granted to a non-resident. American Express Co. v. Fox, 135 Tenn. 489,187 S. W. 1117 (I9I6). Contra: Busby v. Munday, 5 Madd. 297 (I821).

${ }^{\text {to }}$ Griffith v. Langsdale, 53 Ark. 7I, 13 S. W. 733 (1890). Mesner, supra note 22, 2t 499, suggests that the lack of power of. the courts to enforce 2 decree against 2 non-resident should not alone be 02 sufficient reason for their sefusal to act, as he could be required to put up a bond, or, if he has local property, it could be sequestered. He submits, however, that this is not a matcer of jurisdiction at all, "but merely a refusal to act in such 2 siruation because, on grounds of comity, the power of one state to interfere with a litigant, who is in due course pursuing his rights and remedies in the courts of another state, ought to be sparingly exercised. When one of the parties is a non-resident, the reason for granting the injunction on the grounds of convenience of witnesses, expense, cvasion of the laws of the domicil, and other grounds commonly invoked will mostly likely be lacking, but, if the proper case is shown, there does not seem to be any objection to granting such relief, even in case one of the parties is 2 nonsesident, provided he is subject to the jurisdiction of the court."

"Soe note 19, supra.

In all the reported eases, we have found the equity plaintif to be a resident of the enjoining state.

2 Thus, New York will frequently recognize an ex parte divorce obtained against a non-resident which would not be recognized as against a resident. See Ball v. Cross; Dean v. Dean, supra note 48.

"See Note (1933) 28 In工. L. REv. 295, 296: "The b2sis of such an injunction is the power to compel a citizen to continue obeying the laws of his own state, although beyond its territorial limits. Since a state has no recognized power either to prevent a change of domicil or to compel a former citizen to continue obeying its laws after 2 change of domicil, such an injunction depends for its effectiveness upon the continued domicil of the defendant within the jurisdiction of the restraining court. The ordinary action in a foreign court, restrained by injunction, is one which the defendant could maintain without removing his domicil from the jurisdiction of the enjoining court. A divorce action, however, can only be prosecuted in the court of a foreign state by a removal of domicil to that state, and between sister states a change of domicil constitutes a change of citizenship."

THorda v. Bord2, supra note 52. And here the facts were peculiar. The husband petitioned for divorce in Rhode Island; the wife filed a cross-petition asking for divorce. The busband did not prosecute his petition, but after the filing of his wife's motion sought leave to discontinue, which was not permitted. Prior to the hearing the husband was enjoined from prosecuting a proceeding for divorce which he had instituted in Porto Rico after the filing of his petition and the potion of the wife. The divorce was 
been granted, the equity defendant was a domiciled inhabitant of the enjoining State. In a number of cases the equity defendant has claimed the acquisition of a new domicil, which was not recognized by enjoining court. ${ }^{76}$ In some cases the equity defendant admitted that his domicil remained unchanged. ${ }^{7 T}$ If the equity defendant honestly intends to establish a permanent domicil elsewhere, it would secm that he should not be enjoined from divorce proceedings. In such cases it has been said that the burden of going forward with the evidence rests on the defendant. ${ }^{78}$ Quacre whether this would be so with a state having a divorce policy similar to New York. ${ }^{70}$

Will an injunction be granted where the equity defendant cannot be served within the state? Where this is impossible the New York courts have refused a divorce injunction. ${ }^{80}$ This has been due to the belief that contempt proceedings could not be based upon foreign service. ${ }^{81}$ In all the New York cases where such an injunction has been granted there has been service on the equity defendant within the State. ${ }^{82}$ This position seems entirely justified in view of the nature of the

granted the wife and was affirmed on appeal. Sweetland, C. J., at p. 339: "The exact domicil of the petitioner at the time of filing his petition is somewhat uncertain. He clearly was not a domiciled inhabitant of Rhole Island. The petitioner being without a domicil in this state was obliged to rely upon the domicil of his wife in order to give the Superior Court jurisdiccion over his petition for divorce."

To Dublin v. Dublin, supra note 1. Defendant husband claimed that he had established a domicil in Pennsylvaniz and was entived to bring divorce proceedings there. Held, wife entitled to injunction. Horton, J., at p. 695: "Whether it (the court) will exercise its power (to enjain) in this case depends entircly upon whether defendant's domicil is in the state of New York or in the State of Pennsylvania." At pp. 696-7: "Upon the evidence the court is compelled to find that the defendants" alleged domicil in Erie (Pennsylvania) was not and was not intended to be his permanent home; that it was pretense only and is sought to be established by him in bad faith and for the purpose only of giving him a colorable right to maintain his action for divorce against his wife."

See also Gwathmey v. Gwathmey, supra note 5I; Streitwolf v. Streitwolf, supra note 50; Di Brigidia v. Brigidia, supra note 67 .

$\pi$ Johnson $v$. Johnson, supra note $x$. The defendant husband appeared, but did not answer or make any denial of the plaintiff's allegations that he was domiciled in New York; he admitted his -intention of establishing a fictitious residence elsewhere. Sce also Greenberg v. Greenberg, supra note 48.

Kempson v. Kempson, supra note 50, at 98; Huettinger v. Huettinger, supra note 50, at 575 .

Tuppose a New York marriage; the husband leaves the wife without cause; he goes to California where he lives for five years, and then sues for divorce on a ground not recognized in New York. The wife, continuing her New York residence, seeks an injunction restraining the California divorce proceeding. Assuming service on the husband in New York, would the injunction issue? Would such a divorce be recognized in New York?

- May v. May, supra note 1 .

abid. Husband sued for separation on the ground of abandonment, the summons and complaint being served on the wife in Nevada. Shortly thereafter the husband obtained an ex purfe oider directing the wife to show cause why she should not be enjoined from secking a divorce or separation from the plaintiff in Nevada. This order was also served in Nevada. Upon the return day of the motion, the defendant wife appeared specially to contest the jurisdiction of the court. "We are further of the opinion that the court at Special Term also improperly granted the motion for injunctive relief. While it is true, of course, that the court has power to enjoin one served within the srate from prosecuting an action in another jurisdiction, and that such relief, if granted here, would be in furtherance of the court's power to adjudicate in respect to the res, it would be 2 mere futile gesture under the circumstances here presented. There could be no contempt predicated upon the service of such an order without the jurisdiction. Ebsary Gypsum Co. v. Ruby, 256 N. Y. 406, 176 N. E. 820 (1931). . . . " OMalley, J., at p. 521.

- Forrest v. Fortest, supra note 51; Kittle v. Kittle, supra note 51; Gwathmey v. Gwathmey, supra note 51; Greenberg v. Greenberg, supra note 48; Johnson v. Johnson, supra note I; Richman v. Richman, supra note I; Dublin v. Dublin, supra note 1. 
divorce injunction. Different is the practice of the New Jersey courts. ${ }^{83}$ There such an injunction will issue after foreign service, even though the equity defendant has been continuously absent from the State. ${ }^{84}$ The leading New Jersey decision upon the point is Kempson v. Kempson.85 Suit had been filed in New Jersey to enjoin complainant's husband from proceeding with a divorce in North Dakota. The injunction had been granted. In the Court of Errors and Appeals ${ }^{80}$ the controversy arose over the attachment of the defendant for contempt in violating the order-he attacked the jurisdiction of the New Jersey court. It had been alleged by the complainant (who was at all times domiciled in New Jersey) that the defendant was at all times a resident of New Jersey; but he was not in New Jersey at the time of the injunction proceedings, though he was given notice of them and was served with them in New York. It was held, that the court had jurisdiction; that the injunction was properly granted. ${ }^{87}$ The court proceeded on the ground that the bases for this action need be only the same as the bases for divorce; that both kinds of actions involve a "res." Hence, as New Jersey was the domicil of the plaintiff and the matrimonial domicil, its courts had jurisdiction. ${ }^{88}$ The New

- Kempson v. Kempson, supra note 50; von Bernuth v. von Bẹnuth, supra note 50 (service upon the defendant husband was in New York); Perlman v. Perlman, supra note I (service of the restraining order made upon the defendant husband in Nevada); Knapp v. Knapp, supra note 1 (service of order made in New York); Di Brigidiz v. Di Brigidia, supre note I (service of the injunction made upon the defendant husband in Nevada).

an Knapp v. Knapp, supra note I, the husband deserted his wife in New Jersey and went to New York, the wife continuing her New Jersey residence. Later the wife was served with process in a suit for divorce against her in Mexico. . Whereupon this application was made for an injunction restraining her husband from prosectiting such a suit in Mexico. No service was effected upon the defendant in New Jersey, but an order was'made requiring the defendant to appear, which order was served personally upon him in New York. He failed to appear. Held, plaintiff was entitled to an injunction.

supra note 50. The wife asked the court to restrain her husband from further proceeding with his divorce suit begun against her in North Dakota on the ground of cruelty, not then a ground for divorce in New Jersey. Service of the complaint and summons in the divorce suit was made upon the complainant in New Jersey. The wife alleged that the husband's allegation of residence in the North Dakota divorce complaint was fraudulent. She asked for custody of the children of the marriage. An injunction was issued pending this suit in regard to the custody and maintenance of the children. The order contained leave to serve it on th: defendant wherever he might be found. The injunction was served upon the defendant personally in New York.

Kempson v. Kempson, 61 N. J. Eq. 303, 48 Atl. 244 (1901). The husband, in spite of the injunction, obtained the divorce in North Dakota. After his remarriage, he returned to New Jercey, and the wife sought to charge him with contempt. The question arose as to the effectiveness of the service of the order. "With regard to the actual service of the' writ out of the jurisdiction: It seems to be well settled that it is a matter of no consequence how the fact of the issuing of the injunction is brought to the knowledge or notice of the defendant. If he has notice or knowledge of it, his conseience bound, and he is liable to the consequences of its breach to the same extent 25 if it has been actually served upon him in writing. The (New Jersey) authoritics abundantly sustain the position that the service of an injunction may be made without the jurisdiction, and that mere knowledge by the party of the existence of the injunction is sufficient, without any actual service, to put him in contempt for its violation. . . . I therefore conclude that the injunction was served. But besides that, there is abundant evidence in the case that he bad notice, from something more reliable than mere rumor, . . . of the existence of the injunction." Pitney, V. C., at p. 310.

Kempson v. Kempson, 63 N. J. Eq. 783, 52 Atl. 360, 625 (1902).

"In regard to the modification of the decree in attachment procecdings, 'see note 124 , infra.

"Dixon, J., p. 784: "It may be regarded as settled, by 2 long train of adjudications, culminating in Atherton v. Atherton [supra note 10], that the state, wherein are the matrimonial domicil and also 
Jersey courts proceed upon the theory that the injunction may issue against one domiciled therein, though temporarily absent, provided he is properly served, according to the laws of New Jersey, either constructively, or personally outside the state, if he have actual notice of the injunction. ${ }^{82}$ In view of the extraordinary nature of this relief, it is submitted that the New York view is more preferable.

Suppose that one spouse has already begun a suit for divorce in another jurisdiction, will a court of the domicil of the other spouse issue an injunction to restrain a further prosecution thereof? In the early New York case of Mead v. Merritt, Chancellor Walworth intimated that after a suit had once been commenced in a foreign court, no injunction would issue to restrain further proceedings because such would be inconsistent with interstate comity.91 In a later case, ${ }^{92}$ Chancellor Walworth said: "It must be a very special case which will induce it to break over the rule of comity, and of policy, which forbids the granting of an injunction to stay the proceedings in a suit, which has already been commenced, in a court of competent jurisdiction in a sister state." The distinction drawn by Chancellor Walworth has not been followed by the great majority of courts in this country. ${ }^{93}$ In Forrest $v$. Forrest ${ }^{94}$ the wife sued for a divorce on the ground of adultery and also for an injunction restraining her husband from proceeding with the prosecution of a divorce suit begun in Pennsylvania. The injunction was granted, Edmonds, J, dis-

the dumicil of complaining spouse, has the right to confer upon its court jurisdiction over the matrimonial status, no matter where the other spouse may be. In such circumstanees the matrimonial status is deemed to have a situs within the state resembling, for the time being, the situs of land, and the proceeding respecting that status in guasi in rem. This power is recognized and upheld by foreign states, provided the state exercising it has made and carried out reasonable provision for giving to the defendant notice and an opportunity to be heard. ....

For the purpose of pronouncing a decree in the cause there must be appearance by the defendant, or process served upon him within the state, or publication of notice to him. . . But, for the purpose of giving effect to a preliminary injunction, nothing more is needed than that the defendant should have received due rotice of the injunction. ...

"In the case now before us, the matrimonial domicil and the domicil of the complainant being actually within the state when the bill was filed, the court had the right to proceed to final decree against the defendant, even though he remained absent from the state, and therefore to require his obedience to the injunction, of which he had notice."

We are again confrocted with the rather misleading character of the "in rem" language. Nore further that in divorce actions, alimony can be granted only on in personam. jurisdiction. Is the question not really the same here?

- Sec Restatement, Confzet of Lawh, 547.

2 Paige 402 (N. Y. 1831). The injunction sought to restrain defendants from applying to the Court of Probates in Connecticut.

In Busby v. Munday, 5 Madd. 297 (1821), an injunction was issued although a suit was already pending in Scolland upon a bond.

"However, Chancellor Walworth said: "Independent of this question of jurisdiction, it is evident that the complainant has no right to the equitable inierposition of this court" 2 Paige 402,406 (N. Y. 1831 ).

"Burgess v. Smith, 2 Barb. Ch. 276,280 (N. Y. 1847).

- Cole v. Cunningham, supra note 27; Dehon v. Foster, supra.note 28.

- Sagra note $5 x$. 
approving Mead $\nu$. Merritt in regard to the distinction above noted. ${ }^{95}$ In the larg majority of cases where the courts have considered the granting of an injunction t restrain divorce proceedings elsewhere, the divorce suit has actually been com menced. ${ }^{\theta 6}$ That is, if the equity plaintiff is otherwise entitled, the injunction $x \varepsilon$ straining the divorce proceedings will not be denied because the foreign proceeding have already been commenced. Because of the very nature of the divorce proceeding! less weight should be given to the fact that the suit has been initiated abroad thas in other cases where the equity defendant has a definite choice of forum. ${ }^{.7}$

The fact that the divorce sought to be enjoined would be void and of no effec in the enjoining state will not prevent the issuance of the injunction. ${ }^{08}$ There ha

"Ai p. 185: "Buq, if the distincrion is well taken, it cannot be mado to apply to a cace where th foreign tribunal is not competent to grant full and adequate relief."

The defendane husband claimed that he had changed his residence to Pennsylvania and was therefor entitled to bring divorce proceedings there. "But if he did so change his residence, and that for th purpose of giving the courss of that state jurisdiction of his case, nothing is better settled in our court than that such temporary residence, for the purpose of conferring juritdiction, is in fraudum legis and will be disregarded. ..." At p. 184 .

"It is manifest. . that the defendant cannot obtain, in his suit in Pennsylvana, a decree whisl can be binding on his wife bere." At p. 786.

A new idea is here introduced, namely, the ineffectiveness of the contemplated Pennsylvania decres

${ }^{\infty} \mathrm{New}$ York cases: Forresi v. Forrest, supra note $5 \mathrm{I}$ (in Pennsylvania); Rittle v. Kittle, supro note 5 : (in Connecticut); Gwathmey v. Gwathmey, supra note $5 I$ (in Florida); Greenberg v. Grcenberg, supr note 48 (in Moreles, Mexico); May จ. May supres note 8 (in Nevada; injunction denied because eervie out of state); Richman v. Richman, supra note I (in Mesico); Dublin v. Dublia, supre nose I (in Pennryl vania).

New Jersey cases: Streitwolf $\nabla$. Streitwolf, supra note 50 (in North Dakora); IJuettinger $\nabla$. Huctinger suspe note 50 (in South. Dakota); Kempson จ. Kempron, sspro nore 50 (in Norb Dakota); Milles v Miller, sipra note 50 (in South Dakoze); von Bernuth v. von Bernurh, supgo note 50 (in Nev Yorts) Berlman จ. Perlman, supra note 1 (in Nevada); Rnapp v. Knapp, ssspra nore I (in Mexico); Di Brigidis v Di Brigidia, zupra note $I$ (is Nevada).

"Particularly is this ine in New York where the court do nor recogaize a forcign ex parte divore against a cirizen of Negr York. Haddock $\nabla$. Haddock, supra note 17; People $\nabla$. Baker, supro nore 20 Fischer v. Fischer, supro note 48 ; Lefferts $\nabla$. Lefferts, supro note 48.

New Jersey will recognize an ex parte divorce by a state in which the plaintif was domiciled, i such decree might have been obtained in New Jersey on the same ground, and these has beea sucl service on the defendant as gives him notice and a reasonable opportunity to appear. Schneider v Schneider, 103 N. J. Eq. 149, I43 Atl. 417 (1928); Ballantine จ. Ballartine, 112 N. J. Eq. 222, 164 Atl. ! (1933).

In Greenberg 7 . Greenberg, supra note 48 , the husband brought an action for divorce in Ner: York. Before the determination of these proceedings, and while both parties were residents of Nen York, he began a similar action in Mexico, upon grounds not recognized in New York, and under con ditions such that the decree would be void in New York. The wife brought this action to enjoin furthe prosecution of the divorce action in Mexico. Held, an iojunction should be granted.

Dowiing, J., pp. 215, 116: "Nor is it an answer to this application for relief to say that the decre of divorce sought to be obtained in Mexico will be invalid in this State and, therefore, plaintiff need no injunction to prevent its issuance. The defendant cannot be presumed to have gone to the expenx and trouble of placing himself under the jurisdiction of the courts of Mexico as a mere gesture o protest or spite. He is endeavoriag not merely in that forum to obtain a decree of divorce but a question the legitimate birth of his child and to settle tho amount be is to pay for the maintenance o wife and child here. He sags he is now advised by his counsel (presumably his New York counsel; that a decree obtained in Mexico under the circumstances present in his case there, is absolutely nul and yoid so far as this plaintiff is concerned. Why then does be object to his useless action being 
been some authority ${ }^{99}$ to the effect that while an injunction would be proper when the foreign divorce decree would be valid in the jurisdiction rendering it, "the propriety of an injunction is not so clear when the divorce decree of the foreign jurisdiction would be wholly invalid, since it is usually said that a court of equity will not intervene to restrain a proceeding wholly void, just as it will not entertain an action to remove a cloud on title when the instrument giving rise to the cloud is void on its face." It is submitted that this position is untenable. ${ }^{100}$ It would seem that the ex parte divorce is valid at least in the state of the forum. Nor does the fact that the equity plaintiff will suffer no financial loss prevent the issuance of the injunction. ${ }^{101}$ True, after the foreign divorce, the plaintiff wife could sue for separate maintenance. ${ }^{102}$ Plaintiff wife can still get dower or the statutory substitute in some states. $^{108}$

enjoined and why does he fail to abandon it, but on the contrary resist any attempt to halt its progress? If he were allowed to prosecute his Mexican action to judgment, undoubtedly he would then find Mexican counsel to advise him that his divorce obtained there was valid in Mexico, and that he was free 10 contract 2 second marriage in that country. Thus plaintiff would be in danger of having hes status assailed and her rights invaded by having a husband with one wife in New York and anothes in Mexico. ...

"A wife who has given no ground for divorce in this State where she and her husband have always lived during their married life, should not be exposed to the humiliation and doubt as to her stanis raised by a judgment of divorce in another State, even if fraudulently obtained and invalid here.

"There are many conceivable uses to which such a judgment of divorce could be put, causing plaintiff expense, litigation, worry, annoyance and misrepresentation. It is no answer to say that she must ultimately succeed against any attack made upon her, under the judgment, $2 s$ it is invalid."

To the same effect, Johnson v. Johnson, supra note I; Richman v. Richman, stupra note I; Gwathmey $\nabla$. Gwathmey, supra note 5I; Forrest v. Forrest, supra note 51.

Sce (1926) iI MrNs. L. Rev. 467, 468.

${ }^{100}$ Ibid: "In dealing with what might perhaps be called a "cloud on the marriage status," the court [in Greenberg v. Greenberg] allows the practical objections to such 2 "cloud' to prevail over the logical proposition that anything cntircly void cannot be a cloud."

${ }^{201}$ Johnson v. Johnson, supra note I at 95, Hefferman, J.: "Counsel for defendant contend that the court is powerless to protect plaintiff by injunction against defendant's threatened wrong, on the theary that she is not damaged financially. That argument is readily refuted. Defendant is attempting to annul plaintiff's status as his wife and thereby invade her personal rights. There are other things in life besides mere money damages. Not every element of wrong can be estimated and ascertained in dollars and cents. Because the pecuniary injuries which plaintiff may sustain, if defendant should accomplish his purpose, cannot be measured with mathematical accuracy, is no reason for bolding that she is outside the pale of the court's protection."

${ }^{100}$ Garabrant v. Garabrant, 95 N. J. Eq. 136, 122 Atl. 848 (I923) (Oklahoma divoree); Sechler v. Sechler, 94 N. J. Eq. 47, 218 Atr. 629 (1922) (Nevada divorce); Robins v. Robins, to3 N. J. Eq. 26, 142 Atl. 168 (1928) (Mcxican divorce); Reik v. Reik, 109 N. J. Eg. 615, 158 Atl. 519 (1932) (Mexican divoree), aff'd I12 N. J. Eq. 234, 163 Atl. 907 (1933); Di Brigidia v. Di Brigidia, supra note I (Nevads divoree).

${ }^{100}$ The New York Decedent Estate L2w, N. Y. Coss. Lsws (Cahill, 1930) c. 13, 587, provides: 'No distributive share of the estate of a decedent shall be allowed under the provisions of this article, citber (a) to 2 spouse against whom or in whose Eavor a final decsee or judgrant of divorce recognized as valid by the law of this state has been sendered; (b) or to 2 spouse who has procured without thestate of New York a final decree or judgment dissolving the marriage with the decedeat, where such decree or judgment is not recognized as valid by the low of shis state." (Italics authar's.) 


\section{The Effectiveness of the Injunction Restraining Divorce Proceedings OUTSIDE THE DOMICIL}

\section{r. Legal Consequences.}

What is the efficacy of the injunction ${ }^{104}$ of State $X$, effectively issued, restraining divorce proceedings elsewhere? It has been suggested that the issuance of such an injunction against the usual foreign suit is, in effect, a judicial determination that no court but that of State $X$ is an appropriate tribunal to hear the particular cause, "something in the nature of a negative doctrine of forum non conveniens." injunction would seem to be based on a judicial determination that the equity defendant had not the necessary domiciliary requirements to maintain an out-of-state divorce suit, ${ }^{108}$ at least at the time of the injunction hearing; and that he had no statutory grounds on which to proceed to a divorce. ${ }^{107}$ Whether the injunction be temporary or permanent in character, the hearing would seem to decide no more than this. The injunction in Johnson $v$. Johnson ${ }^{108}$ was an in personam restraint upon the husband, in his capacity as a citizen of New York, enjoining him, pending the hearirg on his wife's suit for separation, from fraudulently evading the laws of New York and proceeding to a divcrce elsewhere. That is, that at the time of the injunction, there was no other court where he could so proceed. The injunction, however, could not prevent a change of domicil, and were he in good faith to effect such a change of domicil and citizenship, the basis of the injunction would seem to be destroyed. ${ }^{109}$ He would then be in a position to institute a valid foreign divorce action. ${ }^{110}$

What is the likelihood of the equity defendant proceeding with the foreign divorce in disregard of the injunction? The chances are that the injunction will be an effective restraint. ${ }^{111}$ In the six cases, cited in the footnote, ${ }^{122}$ despite the injunction, the equity defendant has proceeded to obtain an ex parte divorce. In only two of these cases was the equity defendant before the court of the restraining

${ }^{20}$ The 2uthority to pronounce such a deeree carries with it, of course, the power to punish disobedience thereof through contempt proceedings. See note 114 , infre.

200 Note (1933) 31 MrCH. L. REv. $963,966$.

200 Domicil, however, is a jurisdictional fact, supre note 21.

200 That is, in the enjoining state.

200 Supra, note 45.

${ }^{100}$ Note (1933) 28 ILL. L. REv. 295, 296: "Presumably, however, the defendant is not forever bound by this expressed intent (to prosecute 2 foreign divorce without a change of New York domicil) and could change it to one consistent with the establishment of an actual foreign domicil which would destroy the New York citizenship of the defendant which forms the basis of his personal restraint."

${ }^{\text {wo }}$ But would such 2 divorce be recognized in New York if the divorce defendant, continuing her New York residence, were not personally served within the divorce state and did not appear in the suit? Probably not. See note 48 , supre. In regard to the recognition of such 2 decree in New Jersey, sce note 97, supra. See also 2 N. J. Comp. Stat. (1910) p. $2041,533$.

${ }^{12}$ Even though the equity defendant obtains his divorce, be must forever remain out of the enjoining state through fear of contempt proceedings. Furthermore, his property there would be subject to sequestration. For the average property owner these would seem to be sufficient deterrents.

${ }_{12}$ Kempson v. Kempson, supra note 50; Perlman v. Perlman, supra note 1; Di Brigidia v. Di Brigidia, supra note 1 ; Streitwolf v. Streitwolf, supra note 50; Gwathmey v. Gwathmey, supra note 5x; Borda v. Bord2, supra note 52. 
state for contempt. ${ }^{113}$ In each case there was punishment therefor. ${ }^{114}$ Should the restraining divorce plaintiff proceed to a decree and not return to the enjoining state, presumably he could not be punished. The rule to show cause must be served in person. His local property, however, might be sequestered.

A distinction must be noticed between the cases: first, where the equity defendant, at the time of the restraining order, has already commenced the foreign divorce proceedings, and second, where no such steps have as yet been taken.115 In the latter case, compliance with the injunction is simple. In the former situation the equity defendant must consider whether he has the power to dismiss the foreign divorce suit.118 Recalling that in our typical set-up the divorce defendant does not desire a decree, it would seem that the court should allow a non-suit. A very different problem would be presented if the divorce defendant appeared and objected to the dismissal at the instance of the plaintiff therein. ${ }^{117}$

So far we have considered the injunction from the standpoint of the equity defendant, and of the enjoining state. What about the exterritorial effect of such restraining order?118 Is it entitled to protection under the full faith and credit clause of the Federal Constitution? ${ }^{119}$ Will there be a discretionary recognition of the equity decree? Or will it be disregarded entirely with the result that the divorce suit

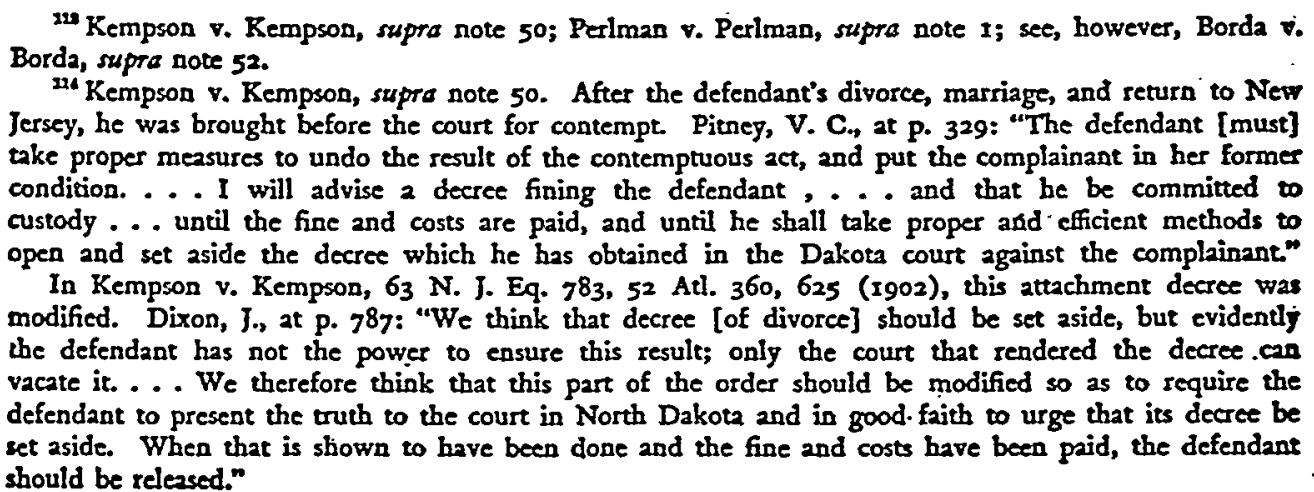

A similar order was made in Perlman v. Periman, supra note $I$. Jereet.

It is interesting to notice that in both these cases the injunction order was not served within New

2if See noto 96 , supra.

211 In regard to the injunction against foreign suits in general, it is said, (1932) 3r Mrcrt. L. Rev. 88, 92-93: "When he obeys the decree and dismisses his action abroad, be is exercising the power available to any plaintiff. That he may do so without prejudice up to the time of the trial is generally held. After that point it is within the discretion of the court to determine whether a non-suit may be entered without prejudice."

11y See Borda v. Borda, supre note 75.

210 In discussing this in general, (1930) 39 YaIX L. J. 719, 720: "But to a defendant, seeking relief from a vexatious forcign suit, the issuance of the injunction and the threat of negative "cnforeement" are of no more than contributory importance. His ultimate concern is with the positive prohibitive effectiveness of the injunction in preventing the foreign suit. This effectiveness is dependent upon the active recognition which will be accorded the injunction by the courts of the sister state when the plaintiff disobeys the decree and attempts to sue"

210 See note 19, supre. 
will proceed on its merits? ${ }^{120}$ If the foreign divorce court were likely to dismiss the suit on the ground that it is not the appropriate forum, the need for the issuance of the injunction would cease. The injunction is issued on the apparent assumption that the foreign court will take jurisdiction. And such has been the clear practice of the divorce "shops."

These are highly controversial matters, even when dealing with an ordinary injunction restraining a suit on a transitory cause of action. Unfortunately the comparatively few decided cases upon this point deal with types of litigation which can generally be maintained by non-residents. ${ }^{121}$ On the other hand, a suit for divorce can be maintained only at the domicil of at least one of the parties. ${ }^{122}$ Again, in the decided cases dealing with the exterritorial recognition of the injunction in general, there has been an appearance by the equity plaintiff in the foreign court and the injunction has been offered as a reason for refusing to take jurisdiction over the cause. In the divorce set-up (and there are no reported cases dealing with exterritorial recognition of this type of restraining order) the divorce court most likely will not have notice of the injunction. The equity defendant ${ }^{123}$ will not make disclosure thereof; the equity plaintiff is not likely to appear to contest the jurisdiction of the court and to give notice of the injunction. This not only because of the expense and inconvenience, but also because of the danger of submitting to the jurisdiction of the divorce court. ${ }^{124}$ Furthermore, it is common knowledge that the divorce "markets" of today are all too willing to assume divorce jurisdiction for various reasons, and require nothing more than residence of the plaintiff in the state for the statutory period. ${ }^{125}$

First, does the full faith and credit clause require recognition of the injunction? If not, should there be discretionary recognition? The Supreme Court has not yet spoken on the first point. ${ }^{128}$ The question is rarely alluded to in the state courts.

${ }^{100}$ Much has been written on the exterritorial effect of injunction against suit: Mesner, supra note 22; (1930) 39 YALE L. J. 719; (1933) 31 Mich. L. Rev. 963; (2924) 22 Mich. L. Rev. 469; (1923) 33 YALE L. J. 95; (1924) 72 U. of PA. L. REv. 429; (1923) 37 HARv. L. REv. 157; Note (1919) 1 A. L. R. 148.

if State ex rel. Bossung v. District Court, 140 Minn. 494, 68 N. W. 589 (1918); Union Pacific R. R. v. Rule, 155 Minn. 302, 193 N. W. 161 (1923); Fisher v. Pacific Mutual Life Ins. Co., 112 Miss. 30, 72 So. 846 (1916); Allen จ. Chicago, Great Western R. R., 239 III. App. 38 (1925), are some of the leading cases.

is See note 35, supra.

20 For a typical set-up, see Di Brigidiz v. Di Brigidia, supra note 67.

23x As to the effect of appearance, see Restatement, Conftict of LAws $\$ 451$; also note 63, supre.

For helpful material on this important question which cannot be here discussed, sec Medina, Condusiveness of Rulings on Jurisdiction (1931) 31 CoL. I. REv. 238; Gavit, Jurisdiction of the Subject Mastcr and Res Iudicata (1932) 80 U. OF PA. L. REv. 386; Farrier, Full Faith and Credit of Adjudications of Iurisdictional Facts (1935) z U. of CHI. L. Rev. 552; Notes (1931) 4I Hakv. L. Rev. 1055; (1931) 26 IL工. L. REv. 432.

25 See Note (1933) 77 Minw. I. Rev. 638; also Squire v. Squire, supre note 15 , where an Arkansas court granted the plaintiff wife a divorce although she admitted that she had no intension of making Arkanses her home, on the ground that "the statute relative to jurisdietion (ninety days residence) had been fiterally complied with." Recall the recent "Barbara Hutton" divorce in Reno.

19. All-inclusive dicta, however, are common. See Roche v. McDonald, 275 U. S. 449, 451 (1928). 
In spite of arguments advanced in favor of full faith and credir recognitions ${ }_{3}^{127}$ the only authority is a dissenting opinion in the case of Union Pacific R. R. v. Rule. ${ }^{128}$ It has been said that "if the equity decree were entitled to full faith and credit, the injunction would be in everything but form an order restraining the foreign court itself. Accordingly there is almost no substantial authority for compulsory recognition of the decree in the foreign law court."129 "The Committee on Jurisprudence and.Law Reform of the American Bar Association introduced into Congress a bill which would extend the full faith and credit clause to all equitable decrees. ${ }^{130}$ There is, however, a little authority for discretionary recognition, ${ }^{131}$ but a majority of the rulings on the point have allowed the equity defendant to sue. ${ }^{132}$

We have been discussing the recognition of the injunction against suit in general. How about the divorce set-up? Are there any distinguishing features here which might dictate a definite answer? It is necessary to recall upon what the enjoining state has passed, primarily, that the equity defendant has not the domicil, at the time of the injunction, to sue for divorce elsewhere, and this is a jurisdictional fact; secondarily, that no cause for divorce exists within the enjoining state. If full faith and credit is to be given to this determination, it must be on the basis of res judicata. ${ }^{13 s}$ But what has been decided? First, a question of domicil, a jurisdictional fact, and second that no ground for divorce exists in the restraining state, which finding would not seem to be conclusive as to grounds which might exist in the divorce forum. There would seem, therefore, to have been no real finding of fact upon which could be based the plea of res judicata. When the equity defendant appears in the foreign divorce court, Nevada,-for instance, assuming the court learns of the injunction, what effect should be given thereto? Nevada could then make a further finding of domicil (it being a jurisdictional fact) and determine for itself that the divorce plaintiff was there domiciled. This would not nocessarily go counter to the determination of the enjoining state; recognition could be given to the finding of domicil there up to the time of the injunction, after which there had been a change. ${ }^{134}$ Again because of the jurisdictional character of domicil, the Nevada finding might well not find favor with the courts of New York or New Jersey. The courts of the enjoining state would undoubtedly punish for contempt upon a return thereto. But the theory thus advanced would be sufficient to entitle the Nevada court to ignore the restraint. The injunction merely determined domicil up to the issuance thereof. It could then

${ }^{27}$ Goodalch, Conflict of LAws (1927) 183; (1923) 33 YALE I. I. 95, 96; (1930) 39 YaIX I. I.

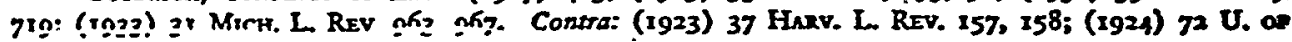
PA. I. REV. 42S, 432.

in Supra, note 12x.

10 Foster, supra note 34, (1930) 43 Hndv. L. REv. 1217, 1245.

${ }^{200}$ See (1927) 52 A. B. A. REP. 292; also (1930) 39 YALE L. J. 719, 725, n. 32.

in Fisher v. Pacific Mutual Life Ins. Co, supre note 121 ; Allen v. Chicago, Great Western R. R, supre note 121 .

240 (1930) 39. Yar. L. I. 719, 721.

in For an excellent treatment of these problems, see Resratevent, Corfirct of IAvs, 55449, 450.

im An interesting analogy is to be found in the recognition given to a decree of custody by anosher atate. 
proceed to find that a cause for divorce exists under its law, while accepting the finding of no such cause under the law of the enjoining state. ${ }^{135}$ "Thercfore, it is submitted, that if the case ever arises, the divi-ce court will not feel fettered by the full faith and credit clause, nor will it be likely to give discretionary recognition to the restraining order. And this even though there had been a contest on the merits over the issuance of the injunction. A more complicated case would be where the divorce suit had already been started at the time of the injunction. ${ }^{190}$ Domicil is supposed to be present at the commencement of the suit.

2. Social Consequences

The conjecture has been made ${ }^{137}$ that the injunction against divorce will be likely, from a practical standpoint, to prove an effective deterrent. This is based upon the assumption that the equity defendant contemplates a continued residence in the forum of the injunction. Otherwise, a legally simple but perhaps practically inconvenient method of avoiding the efficacy of the equitable decree presents itself. ${ }^{138}$

What about the desirability from a social standpoint, however, of this attempt to control migratory divorce? Its social utility has not necessarily been dictated by the observations already made. To attempt to answer this question we must consider for a moment broad divorce policy. In spite of our theory of divorce, based as it is upon old English ecclesiastical practice, that a decree can be granted only to an "in. nocent" spouse against a "guilty" one, ${ }^{139}$ that where there has been proved collusion, connivance, recrimination, or condonation a decree will not issue, divorce practice differs materially. Between the "law in the books" and the "law in action" there is little correlation. Parties, if they desire a divorce, or even if one wishes to break the marriage tie, will, in spite of the theoretical law, obtain a decree. This is, of course, based on the assumption that the parties can bear the necessary financial outlay. Otherwise, "desertion," the "poor man's divorce," is likely to result.140 In other words, the law exercises little deterrent force in divorce.

In all the cases, where an injunction has issued against forcign divorce, there has been an actual family break-up. Little chance appears of affecting a permanent reconciliation on a going basis. And one can hardly imagine that the injunction would enhance this possibility. If anything, it is likely still further to widen the breach. This brings us face to face with the question of whether the interests of society are served by struggling to keep intact what amounts to an empty marriage. Unfortunately, we have no factual studies based on the social desirability of divorce. But it is submitted that society is not served by a preservation of the empty legal

\footnotetext{
150 The equity defendant will be likely to choose a divorce forum.where the causes for divorce differ from those in the enjoining state. See Kempson v. Kempson, supra note 50; Streitwolf v. Streitwolf, supre note 50. .

${ }^{150}$ See p. $3^{8} 3 ;$ supre.

In Note III, supra.

in A change of dumicil to the divorce forum.

100 "There are 2 few "comparative rectitude" statutes. E.g., Nev. Sess. Laws r931, c. 1ro, 330.

${ }^{30}$ See Llewellyn, Behind the Law of Divorce (1932) 32 CoL. L. REv. 1281, 1303, n. 55.
} 
status of matrimony. Even decrees of legal separation have at times been frowned upon. ${ }^{141}$

Accepting then these premises, it would seem that the injunction against divorce should not be favored. It may well have given in many instances an enlarged bargaining power to the equity plaintiff. We have seen that in spite of the void ex parte decree, financial protection is generally secured to the divorce defendant. ${ }^{212}$ Only where such security is threatened by the foreign suit and the remarriage which is likely to follow, should the injunction issue. This was actually the situation in Richman $\nu$. Richman. ${ }^{148}$

\section{The Declaratory Judgment}

What is the efficacy of the declaratory judgment ${ }^{144}$ in regard to a foreign ex parte divorce? Recall our typical set-up. One spouse has left the matrimonial domicil in State $X$ against the wishes of the other, has obtained a divorce in State $Y$, the other spouse neither appearing nor being served with process within the jurisdiction of the divorce forum. A second marriage by the divorce plaintiff is likely to follow. What is the divorce defendant to do? He or she may not care to proceed with his available remedies, namely, divorce, annulment of the second marriage, and, if the wife, a suit for support and maintenance. ${ }^{145}$ What is desired is an authoritative declaration that the foreign ex parte divorce is void and of no effect. In other words, a judgment is sought declaring the preservation and continuance of the marital rights. To what extent can this be obtained through the medium of the declaratory judgment procedure?210

24 Soe 2 Vernier, Axcerican Faumx Iaws (x931) 348.

Note 102, supra.

${ }^{20}$ Supre note 1. Alimony 2 warded the wife, pending her suit for separation, was in arrears. The husband began divorce proceedings in Mexico. An injunction was granted to restrain the divoree procoedings and any attempt by the defendant to marry anyone else. This was based largely on economic grounds.

I" For a comprehensive treatment of declaratory judgments, see the monumental treatise by Borchard. Declaratost Judoncents (1934). Because of the careful treatment there given to every phase of declaratory judgment procedure, the background discussion here will be brief See also Borchard, The Declaratory Judgment-A Needed Procedural Reform (x918) 28 YALE L. J. 1, ro5; Sunderland, A Modern Evolusion in Remedial Righes-The Declaratory ludgment (1917) 16 Mrch. L. Rev. 69 .

Borchard, op. cit., supre, at 629: "The declaratory judgment differs in no essential respect from any other judgment except that it is not followed by a decree for damages, injunction, specific performance, or other immediately coercive relief. It declares conclusively and finally the rights of parties in litigations over a contested issue, a form of relief which often suffees to settle controversies and fully administer justice. It enables parties in disputes over their nghts . . to sue for. 2 declaration of rights ... citing as defendants those who oppose their claims of right. It has been employed in State courts ... for the determination of status in marital or domestic relations. ..."

2010 Note 102 supra.

${ }^{20}$ For a history of the declaratory judgment and English practice, see Bonchnab, op. cit., supre note 144, c. V; also Borchard, supra note I44; Sunderland, supre note I44. For half a cenniry the practice has been common in England.

In 1922 The Uniform Declaratory Judgrnents $A c t$ was approved by the National Conference of Commissioners on Uniform State L2ws. 9 U. L. A. 121. Up to July $x$, 1934, this act had been adopted by nineteen states. Thirtern other states have a declaratory judgment statute. Boncharo, op. cit., supra, 632. For the New York statute, see Crv. PaAc. Act (Cahill, 1925) 3473; Rules of Civil Practice 220-214. 
The determination of questions of status was the earliest function of the declaratory judgment both in Roman law and by specific designation in the English law. The public and private interest in the security and certainty of personal status induced the earliest eatension of judicial power to the determination of doubtful or disputed cases of status." ${ }^{147}$ If the question of status can be determined judicially, it is not necessary to assert or determine the rights consequent thereon; they are merely incidents of the status itself. It is not surprising, therefore, to find that when the divorce defendant, in our typical case, wishes to assert the continued validity of the marriage and at the same time the invalidity of the second marital venture of his spouse, resort should be had to the declaratory judgment. Such was the picture in the leading case of Baumann v. Baumann.148 The wife sued for 2 declaratory judgment pursuant to the New York Civil Practice Act, $5473 .{ }^{140}$ The plaintiff $A$ and the defendant $B$, who have always been domiciled in New York, had been married there in 1909 , and two children had been born. In 1924 a separation agreement was entered into under which $A$ released her dower rights and was to receive $\$ 21,000$ a year. In $1924 B$ left the matrimonial domicil in New York and procured an ex parte decree of divorce in Mexico from a court without jurisdiction of the cause, $A$ neither appearing in the action nor being served with process. $B$ then purported to marry the defendant $C$ in Corinecticut, and returned to New York to live with her as husband and wife. The plaintiff asked, first, for a declaratory judgment to the effect that (x) the plaintiff is the lawful wife of $B ;(2)$ the defendants $B$ and $C$ are not husband and wife; and (3) the colorable decree of Mexican divorce is invalid and of no effect; and, second, an injunction enjoining and restraining the defendants from living together as husband and wife and enjoining the defendants, or either of them, from representing or holding themselves out as husband and wife, and enjoining the defendant $C$ from using the name of MIrs. B. The defendants moved to dismiss the complaint for insufficiency. This motion was

207 Borchard, supra note 144, 28 YALE L. J. 105, 123. For example, the Legitimacy Declaration Aa (1858), 21 and 22 Vict. c. 93, S1; now supplanted by the Legitimacy Act (1926), 16 and 17, Gra V. c. 60, 52. Also the suit in the English ecclesiastical courts, known as "jactitation of marriage," now practieally obsolete. Either party to an alleged marriage could allege that he had never entered into such marriage, and, if suecessful, received a declaration that the marriage had never existed and an injunction restraining the other party fom asserting. the marriage. Such suit could not be maintained by a third party.

${ }^{100} 250$ N. Y. 382,165 N. E. 819 (1929), madifying 224 App. Dir. 719, 229 N. Y. Supp. 833 (1928), off'g 132 Misc. 217, 228 N. Y. Supp. 539 (1928). Reargument denied, 250 N. Y. 612, 166 N. E. 344 (1929).

160 "The supreme court shall have the power in any action or proceeding to declare rights and other legal relations on request for such declaration whether or not further relief is or could be claimed, and such declaration shall have the force of a final judgment. Such provisions shall be made by rulo as may be necessary and proper to carry into effect the provisions of this section."

Rule of Civil Practice 210: "An 2ction in the supreme court to obtain a declaratory judgment, pursurnt to section 473 of the Civil Practice Act, in matters of procedure shall follow the forms and practice prescribed in the Civil Practice Act and rules for other actions in that court"

Rule 212: "If, in the opinion of the court, the parties shall be left to relief by existing forms of actions, or for other reasons, it may decline to pronounce a declaratory judgment, stating the grounds on which its discretion is so exercised." 
granted by the trial court without hearing the plaintiffs evidence, on the ground that $A$ had a remedy by action to annul the second marriage. ${ }^{150} \mathrm{Held}$, on appeal, ${ }^{151}$ however, that upon the facts stated in the complaint the plaintiff was entitled to some relief, and the-order dismissing the complaint for insufficiency was reversed. Whereupon at the trial of the case, ${ }^{162}$ judgment was granted for $A$ adjudging and declaring the purported Mexican divorce and the Connecticut marriage to be null and vord, and that $A$ was entitled to injunctive relief. This was affirmed without opinion by the Appellate Division. ${ }^{153}$ In the Court of Appeals the judgment was modified by striking out the restraining clauses, ${ }^{254}$ and, as so modified, was affirmed. "The plaintiff has secured a declaratory judgment which adjudges that she is the lawful wife of the defendant Charles Ludwig Bauman; that the defendants are not and never have been husband and wife; that an alleged divorce procured by the defendant Charles Ludwig Bauman from the plaintiff in Yucatan, Mexico, is null and void; and that an alleged marriage between the defendants . . . is null and void. The findings and evidence justify the judgment to that extent."

100 N. Y. Crv. Prac. ACr. (Cahill, 1925) \$r134: "An action to annul a marriage upon the ground that the former husband or wife of one of the parties was living, may be maintained by either party during the lifetime of the other, or by the former husband or wife"

20222 App. Div. 460,226 N. Y. Supp. 576 (2928). Merrell, I., at p. 463: "In granting the motion of the defendants the court below seized upon the provisions of nule 212 and assumed to exercise discretion and held that the plaintiff had $a$ remedy in this state which would accomplish all that she secks to zcoomplish in her present action, namely, that the plaintiff might bring an action to annul the masriage. . . . There may be some question as to the right of the courts of this state to adjudieate as to the validity of the Mexican decree of divoree, . . 2nd as to the right of the plaintiff to annul the masriage purported to have been entered into between the defendants. . . Nevertheless, we are of the opinion that the plaintif has substantial personal and property rights which demand an adjudication as to her status in this stase as the wife of the defendant Baumann. . . We think that the action for doclaratory judgment for the relief sought by plaintiff is permissible. . . . Whatever relief the plaintiff may receive by the judgment in this action must be left to the trial. Suffice it to say that in our opinion the plaintiff is entitled to some relief herein, and that she is entitled to have declared her matrimonial status bere with the defendant Baumann. Not only is this a matter of personal concern to the plaintiff, but it may well be that her property rights may be involved as well 28 those of the childrea of the partien"

100 132 Mise. 217, 228 N. Y. Supp. 539 (1928).

210 224 App. Div. 719, 229 N. Y. Supp. 833 (1928).

It is beyond our soope to consider the interesting problems raised by the application for injunctive relief. The Baumann case was folowed on this point by Somberg v. Somberg, supre note 2; and Lowe 7 . Lowe, supra note 2. See Pound, Equitable Relief Against Defamation and Injuries to Personality (Igxs) 29 Haxv. L. Rev. 640; Long, Equitable Jurisdiction to Protect Personal Rights (1923) 33 Yalr L. J. 125; Mareland, Injunctive Control of Family Relations (1930) I8 Kr. L. J. 207; (1929) I7 Cans?. L. Rev. 681; (1929) 29 CoL, L. REv. 213; (1930) 43 Harv. L. Rev. 477; (1930) 28 Mrcz. L. REv. 342; (1929) 78 U. or PA. L. REv. II4; (1934) 82 U. or PA. L. REv. 542. Accord in regard to the denial of injunctive relief, Snedaker v. King, 111 Ohio St 225, I45 N. E. 15 (1924).

250 N. Y. 2t 384 , Hubbs, J. In Morecroft v. Taylor, 225 App. Div, 562, 234 N. Y. Supp. 2 (1929). where the plaintiff was held entiled to maintain $2 n$ action for a declaratory judgment that she was the illegitimate daughter of the defendant, O'Malley, J., said, at p. 564: "In. B2umann v. Baumann the plaintiff -. had various existent remedies open to her for the same specific judgment. She could have suied for separation. She had an action for divorce. She was in a position to have sued in criminal conversation. Yet, with all these other available remedies, she was given the right to bring an action for a mere declaratory juogment"

In Lowe $\mathrm{r}$. Lowe, supra note 2 , following Baumann v. Baumann, the plajntiff wife obtained a declaratory judgment to the effect that a Nevada divorce obtained by her husband was roid. Lehman, It 
In Somberg $v$. Somberg ${ }^{158}$ the plaintiff asked for a declaratory judgment that she was the lawiful wife of the defendant Somberg. In this case the husband $S$, without even bothering to obtain a void foreign divorce, began living with the defendant $B$ as husband and wife. A child $C$ was born. It was generally believed and rumored, in the circle to which the parties belonged, that $S$ had divorced the plaintiff and married $B$. The declaratory judgment . was denied ${ }^{167}$ because the plaintiffs status as the wife of the defendant was secured; because such a declaration is proper only when the circumstances render it useful and necessary to stabilize uncertain and disputed legal relations. The denial of the relief here has been criticized by Borchard. 138

In Henry v. Henry ${ }^{150}$ the husband sought a decree adjudging a Nevada divorce void in New Jersey. The defendant moved to dismiss the bill for want of jurisdiction. The wife had wrongfully deserted the plaintiff in New Jersey, the matrimonial domicil, and proceeded to Nevada to secure a divorce for a cause which occurred while the parties lived in New Jersey and which was not recognized by the law of the latter state. It was further alleged that the defendant did not acquire a bona fide domicil in Nevada. The court found that the divorce was void under New Jersey law. ${ }^{160}$ Leaming, V. C. said:"101 "The sole ground of the present motion is the claim that this court may not determire the validity of a decree of divorce of a sister state except as an incident to other relief, such as a suit for maintenance or divorce in which the decree of divorce of a sister state is interfosed as a bar to the primary relief sought. ... But it may be here appropriately suggested that it is unnecessary to regard the present bill as invoking the statutory divorce jurisdiction of this court. It may be said to be an appeal to the original equity jurisdiction of this court for the protection of complainant against the consequences of defendant's fraud. . . . It will be noticed that no other remedy is open to complainant in this state, since he desires neither alimony nor divorce. Complainant also urges that the bill may be sustained under our act concerning declaratory judgments and decrees." The motion to strike out the bill was denied.

In Schneider v. Schneider ${ }^{182}$ the plaintiff wife married the defendant in New York in 1918. On July 15, 1927, a Paris court of competent jurisdiction, made a stated, p. 201: "Because it (the Nevada divorce) gave color of right to an open claim that the plaintiff was no longer the lawful wife of Lowe, it furnishes a ground for the invocation of the court's power to declare the plaintiffs rights to the legal relation of the parties, in order to preclude possible controversy hereafter."

Ios Supra nove 2.

${ }^{2 \pi}$ Kellogg, J, at p. 4: "A declaratory judgment may be resorted to only when circumstances render it 'uscful and necessary'; where it will 'serve some practical end in quieting or stabilizing an uncertain or disputed jural relation either as to present or prospective obligations. Where there is no necessit for resorting to the declaratory judgment, it should not be cmployed.' The plaintiff's status, as the wife of Somberg, is secure. If rumor cests doubts upon it, no decleration by the court that it is false will be useful to surpress it."

1se Boxchiso, op. cib., supra note 144, at 393 .

200 Supre note 2.

$2 \pi$ At p. 22.

Io N. J. Cosp. Stat. (rgro) p. $204 \mathrm{x}, 333$.
Supre note 2. 
decree divorcing the plaintiff and the defendant. The action, on the ground of desertion, was begun by the husband as a claimed resident of Paris, and the wife appeared and submitted herself to the jurisdiction of that court, but put in no defense. The defendant returned to the United States in August, 1927 , and in the same month married again in Maryland, and now resides in New York with his second wife. On September 15, 1927, the plaintiff appealed from the French divorce, contending that the court was without jurisdiction and the evidence insufficient. She was overruled on the former point and ordered to submit further testimony on the latter. Depositions were taken and-returned to the court, which made no further decision on the matter. The plaintiff began this suit on August 10, 1928, for a declaratory judgment that she is the lawful wife of the defendant; that the Paris divorce is invalid; that the defendant and the woman he married are not husband and wife; and that they be enjoined from living together. The plaintiff contended that the authorization she gave to appear in the French action was fraudulently obtained. The Paris court had found that she appeared voluntarily. The lower court dismissed the complaint. On appeal, this was affirmed. Since the plaintiff had appeared yoluntarily, she was estopped from receiving equitable relief in this court. ${ }^{168}$ It would seem that the court here exercised its discretion in a sensible manner. Quacre whether the result would be the same in a case where there was appearance merely to contest the jurisdiction of the court. ${ }^{104}$

Such then are the leading cases dealing with the granting of a declaratory judgment in our typical set-up. For slight variations in situation, see the cases of Dodge v. Campbell ${ }^{165}$ and Cesareo v. Cesareo. ${ }^{168}$ On the whole, the declaratory judgment has been used rather sparingly in regard to foreign ex parte divorce. This can be accounted for in several ways. The declaratory judgment procedure in this country is of comparatively recent growth. ${ }^{107}$ Again, as we have seen above, ${ }^{108}$ foreign ex parte divorces where there is not coöperation comprise a very small percentage of our total divorces. And in this small percentage of cases the divorced spouse frequently is willing to let matters ride without legal action or else resort to some form of coercive remedy.

How desirable and how effective is this form of relief? The declaratory judgment would seem to be a desirable remedy in our typical set-up, namely, the attack-

\footnotetext{
10 Carswell, J., at p. 72: "In view of the finding of the trial cours, amply sustained, that plaintiff voluntarily appeared in the French action, it must be held that plaintiff is estopped from secking affirmative equitable relief after having voluntarily submitted herself to the jurisdiction of the Paris court. Her act in that respect, and her subsequent acts, have brought about the martial complications which she now secks to utilize for the granting to her of affirmative relief. $\therefore$. Under the circumstances, plaintiff may not have the benefit of the equitable powers of this court and have awarded to her the affirmative relief she seeks, in an action for a declaratory judgment, the granting of which rests in sound diseretion."

insee note 63, supme.

10 128 Misc. 778,220 N. Y. Supp. 262 (1927) affd 223 App. Div. 471, 228 N. Y. Supp. 6r8 (1928); 135 Misc. 644, 238 N. Y. Supp. 666 (I929), aff'd 229 App. Div. 534, 242 N. Y. Supp. 534 (1930). 10134 Misc. 88, 234 N. Y. Supp. 44 (r929).

20 See the authorities cited in note 144 , supres.

In Note 18, supra.
} 
ing of an ex parte foreign divorce. In the first place, by entertaining the suit for a declaration, the court can determine amicably the status of the parties without the necessity of a "hostile" suit. ${ }^{269}$ Secondly it would seem to be a proper case for the utilization of the declaratory judgment procedure. The purpose of the declaratory judgment is to obtain an authoritative definition of certain legal relations. These relations have here been challenged by the foreign divorce and even more so by the possible remarriage thereafter. It makes no difference that the foreign divorce is void and of no effect. Circumstancess may still demand an authoritative decision in regard to it.170 Especially is this so where a ceremonial marriage has followed the procurement of the foreign divorce because of the presumption of a strong character in favor of the validity of such a marriage. ${ }^{171}$ Clear proof is required to overcome it. Thus, the declaratory judgment would seem to have a definite value in settling disputed property rights and marital relationships, at least in a jurisdiction other than the divorce forum, ${ }^{172}$ and in protecting the interests of the spouse who had no notice of the divorce proceedings. ${ }^{173}$ It seems to protect the spouse whose status has been placed in question by the action of the other. "The safeguards which have been set up by the various courts are such as to protect the remedy against abuse, ${ }^{17 t}$ to confine proper cases to the divorce courts, and to afford a remedy to those for whom divorce and maintenance actions do not afford the security and relief which they desire."178 "The spouse who has no desire for divorce should not be. driven to the divorce courts for relief against the foreign decree. Many reasons. may militate against the desirability of such action, religious tenets, a lack of belief in divorce, and many more. Nor should such a spouse be forced to proceed to an action for support. There are many other things in life besides financial matters. And lastly, the declaration that the foreign divorce judgment is void would not seem to be an attack upon the decree of the foreign court. It merely declares that within the declaratory state, where is the matrimonial domicil of the parties and wherein resides the control over matters of marriage and divorce, that the ex parte decree is of no effect. Substantially the same thing is frequently done in the courts of New Jersey and New York when recognition is refused the foreign decree in some ordinary action.

\footnotetext{
10 See Sunderland, supre note 144 , at 76 : "Every case may by this means become, in appearance at least, a friendly suit. . . . It makes the law suit a cooperative undertaking."

I70 See Loive v. Lowe, supra note 155; Note (1934) 82 U. of PA. L. REv. 542, 544: "Whether : given divorce is void is 2 question upon which expert legal opinion may differ; rights may accrue or be lost under a divorce of "record, afterwards ascertained to be "void'; evidence available to prove its invalidiry may be lost with the passage of time, and' the 'void' divgree becomen a valid divorer in practical effect, enabling the procurer thereof to remarry with safety and so cut off property rights of his true wife."

${ }^{172}$ Sé Note (1917) 30 Harv. L. Rev. 500.

${ }^{170}$ In Baumann v. Baumann, supre note I5I, the court purported to determine only the status of the parties within the state of New York. See 222 App. Div. 460, 464 (rg28).

${ }^{270}$ Bonchand, op. cit., supro note 144, at 393 .

r7" The discretionary nature of the relief; the requirement of a real "controversy"; the compliance with the conditions of the usual action, procedural and substantive.

${ }^{173}$ Borchard, op. cit., sxpra note 144 , at 393.
} 
Thus, the declaratory judgment would seem to be a useful weapon with which to attack invalid forcign divorces. It would seem to be a more desirable method than the injunction against the divorce. "The injured spouse is judicially exonerated from all suspicion of marital misconduct. The offending party is warned that the reciprocal rights of the marriage are still alive."178

Would a declaratory judgment, such as that in Baumann v. Baumann, ${ }^{177}$ be entitled to recognition elsewhere under the full faith and credit clause of the Federal Constitution? While there is no decision upon the point, it is submitted that it should be so recognized provided the court granting it had jurisdiction. And where the court granting the declaratory judgment is a court of the matrimonial domicil of the parties and where the procurer of the foreign divorce has returned thereto immediately after the divorce, such jurisdiction would seem to be clearly established. In such a case, the finding that the foreign divorce is void, that the marriage following it is void, and that the parties are husband and wife would seem to be conclusive. ${ }^{178}$

Would a court, of New York for example, grant a declaratory judgment to the effect that no cause for divorce exists? Probably not. It certainly would not do so unless the other spouse had started or threatened to bring divorce proceedings elsewhere. There is no precedent for a declaratory judgment in this situation. ${ }^{170}$ There must be a genuine controversy calling for the adjudication of present rights. In any event, how conclusive would such a declaratory judgment be? It would seem to be to the effect that no cause for divorce existed within New York state. It would not, therefore, seem to be res judicata, for instance, in regard to Nevada, where there are other grounds for divorce.

270 Note (1930) 43 Hakv. L. REv. 477, 480: "And yet this selief may be quite inadequate from any practical point of view. The world will hear for 2 moment, or not at all, of the declaratory judgment, but will continue to see the deserted plaintif, on the one hand, and on thd other, the husband and his paramour consorting as husband and wife."

2ir Supre p. 392.

${ }^{170}$ Even if the judgment were not a judicial proceeding, it might still be 2 "public act" or "record" within the mezning of Art. IV, 52 .

Borchard, The Uniform Act on Declaratory Iudgments (1921) 34 Hinkv. L. Rxv. 697, 7r3: "The declaratory judgment, of course, is res judicata as to the substantive legal relations involved."

Girard Trust Co. v. Tremblay Motor Co., 291 P2. 507, 51 1, 140 Atl. 506 (1928). Moschzisker, C. J.: "Thercfore, our determination of the law governing these facts and of the proper construction to be given this instrument will make the pending controversy res judicata for all future purposes, between the present contestants."

${ }_{\text {ito }}$ Foster, supra note 22, at r241, n. 64: "The recent extensive adoption of declaratory judgment acts, suggest the possibility that the law defendant may request the home state to adjudicate his non-liability, and that such judgment might bar the further maintenance of the action, thus obviating the difficulty of enforcing injunctions which do not involve passing on the merits. The writer knows of no instance where this was done." 